\title{
IUCN
}

\section{Спорт и биоразнообразие}

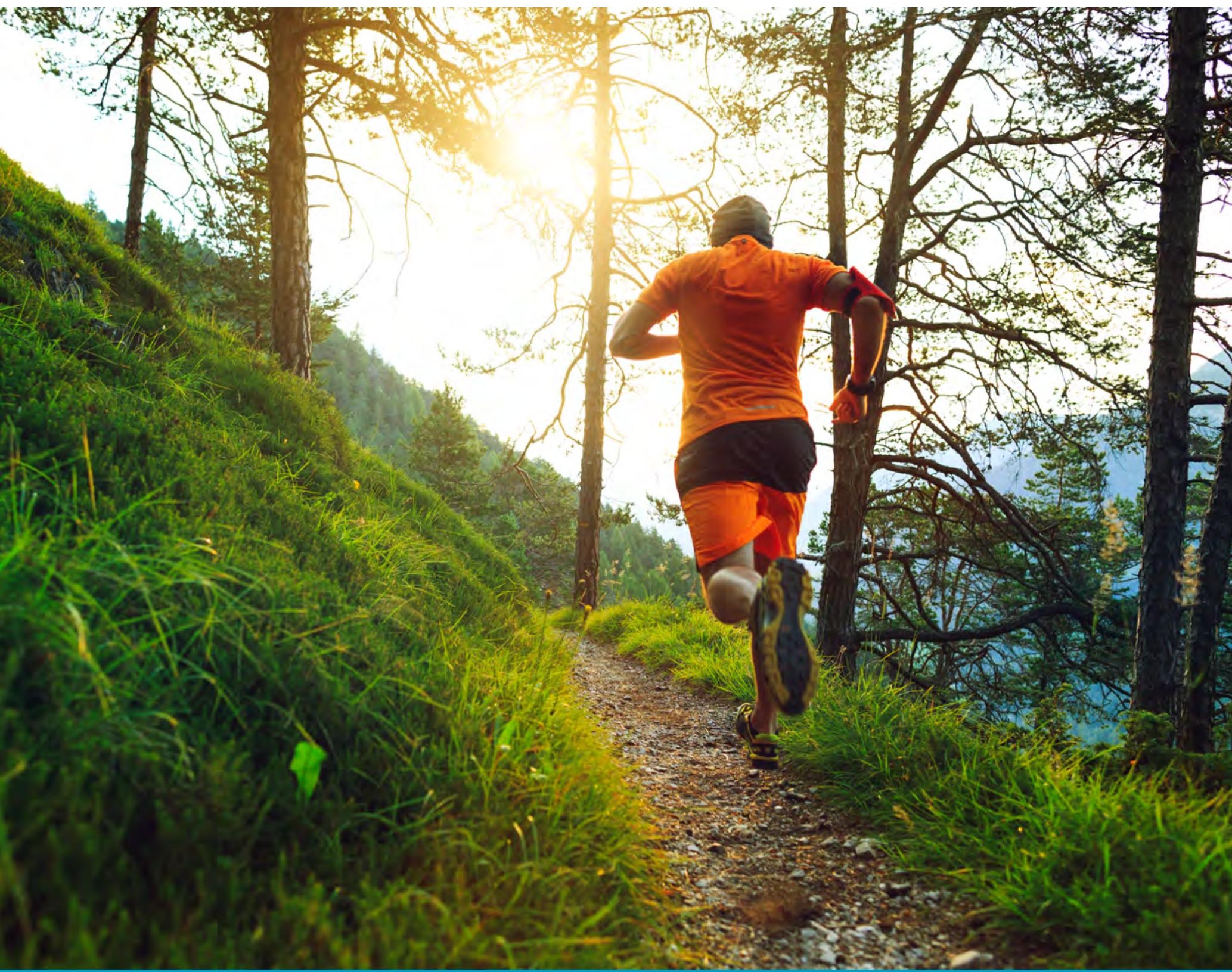




\section{O Mcon}

МСОП-членский союз, состоящий исключительно изправительственных организаций и организаций гражданского общества. Он предоставляет государственным, частным и неправительственным организациям знания и инструменты, обеспечивающие возможность совместного прогресса общества, экономического развития и охраны природы.

МСОП, созданный в 1948 году, в настоящее время является крупнейшей и самой разнообразной экологической сетью в мире, использующей знания, ресурсы и охват более 1300 организацийчленов и около 10000 экспертов. Это ведущий поставщик данных по сохранению, оценкам и анализу. Его широкий круг членов позволяет МСОП выполнять роль инкубатора и надёжного хранилища передового опыта, инструментов и международных стандартов.

МСОП предоставляет нейтральное пространство, в котором различные заинтересованные стороны, включая правительства, неправительственные организации, учёных, предприятия, местные сообщества, организации коренных народов и другие, могут работать вместе для выработки и реализации решений экологических проблем и достижения устойчивого развития.

Работая со многими партнёрами и сторонниками, МСОП реализует широкий и разнообразный портфель природоохранных проектов по всему миру. Сочетая новейшие достижения науки с традиционными знаниями местных сообществ, эти проекты направлены на то, чтобы обратить вспять утрату среды обитания, восстановить экосистемы и улучшить благосостояние людей. 
Спорт и биоразнообразие 
Обозначение географических объектов в этой публикации и представление материала не подразумевают выражения какоголибо мнения со стороны МСОП относительно правового статуса какой-либо страны, территории или области, или её властей, а также делимитации её границ или пространств.

Взгляды, выраженные в этой публикации, не обязательно отражают точку зрения МСОП.

МСОП не несет ответственности за ошибки или упущения, которые могут возникнуть в этом переводе, или отклонения от языковой версии публикации на оригинальном языке. В случае расхождений, пожалуйста, обратитесь к оригинальной публикации. Название оригинальной публикации: Sport and Biodiversity (2018). Издатель: МСОП, Гланд, Швейцария. DOI: https://doi.org/10.2305/IUCN.CH.2018.04.en

Эта публикация стала возможной частично благодаря финансированию Международного олимпийского комитета.

Опубликовано: ананд, Швейцария

Авторское право: 2018 МСОП, Международный Союз охраны природы и природных ресурсов (c) 2021 МСОП, для перевода на русский язык

Воспроизведение данной публикации в образовательных или других некоммерческих целях разрешено без предварительного письменного разрешения правообладателя при условии полной ссылки на источник.

Воспроизведение данной публикации для перепродажи или других коммерческих целей запрещено без предварительного письменного разрешения правообладателя.

Наименование:

МСОП (2021). Спорт и биоразнообразие. Гланд, Швейцария: viii+24 стр.

ISBN:

$978-2-8317-2127-9$

DOl:

https://doi.org/10.2305/IUCN.CH.2018.04.ru

Фото на обложке:

Бег по лесной тропинке (c) iStock

Макет:

Imre Sebestyén jr / Unit Graphics

Перевод:

Ян Цыганков

Доступно из:

МСОП (Международный Союз охраны природы)

Программа Бизнес и биоразнообразие

Rue Mauverney 28

1196 Gland

Switzerland

Tel +41229990000

Fax+41229990002

biobiz@iucn.org

www.iucn.org/resources/publications 


\section{Оглавление}

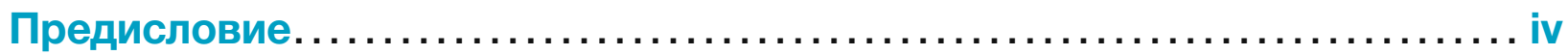

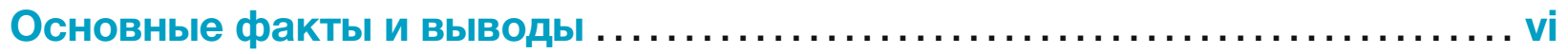

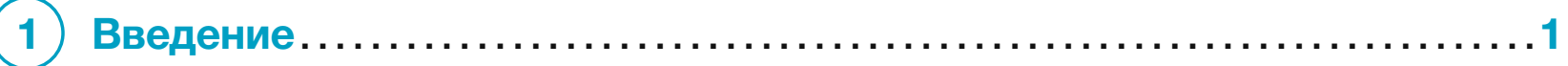

1.1 Цели и область действия данного руководства . . . . . . . . . . . . . . . . . . . . . 1

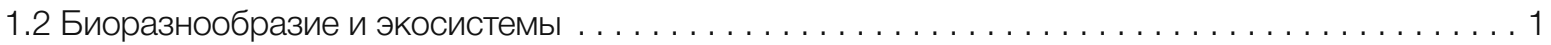

1.3 Биоразнообразие и спорт. . . . . . . . . . . . . . . . . . . . . . . . . . . 2

1.4 Экономическая модель для спорта и биоразнообразия . . . . . . . . . . . . . . . . 3

\section{(2) Управление воздействием спортивных объектов и спортивных}

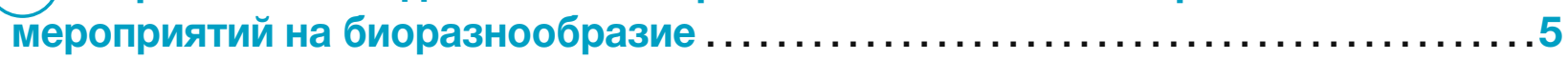

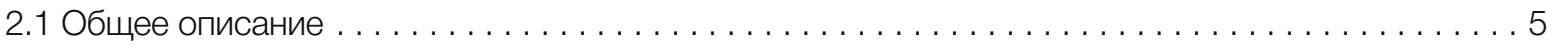

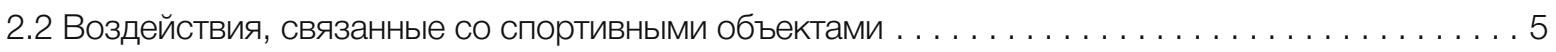

2.3 Воздействия, связанные с организацией спортивных мероприятий. . . . . . . . . . . . 6

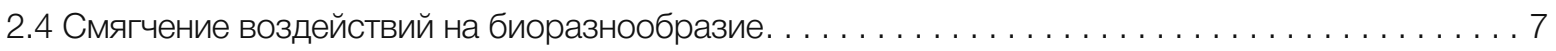

\section{3 Максимальное расширение возможностей сохранения}

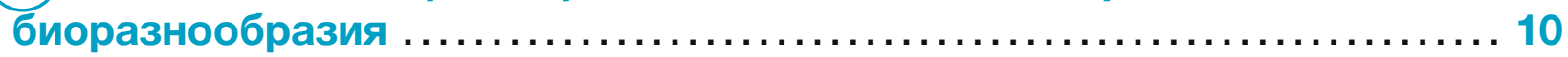

3.1 Улучшение, восстановление и воссоединение естественных сред обитания в городской среде . 10

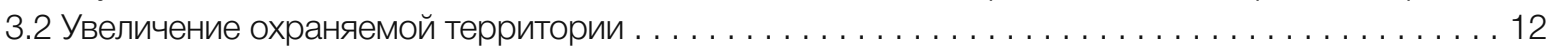

3.3 Создание фондов для финансирования управления охраняемыми территориями . . . . . 13

3.4 Повышение осведомлённости общественности о биоразнообразии . . . . . . . . . . . . 13

3.5 Расширение имеющихся данных и знаний о биоразнообразии . . . . . . . . . . . . 15

3.6 Получение выгод для биоразнообразия за счёт компенсации выбросов углерода . . . . . . . . 15

(4) Контрольный список действий для снижения риска и использования

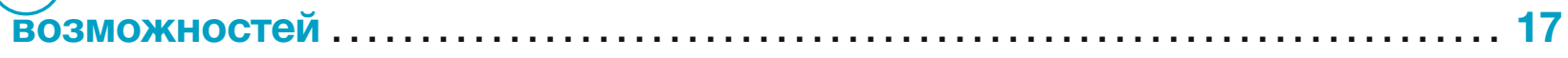

(5) Словарь терминов и источники информации .................. 20

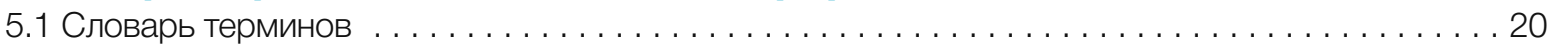

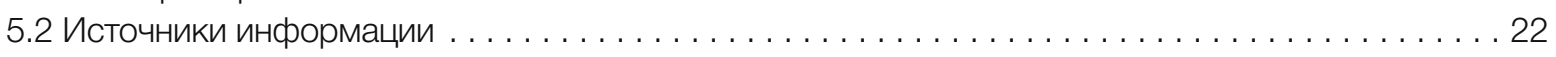




\section{Предисловие}

Ожидается, что к 2030 году население мира достигнет 9 миллиардов человек, поэтому наша природная среда сталкивается с беспрецедентной нагрузкой из-за деятельности человека.

Но давайте проясним: нам нужна природа. Сегодня мы участвуем в гонке за защиту богатых экосистем, которые обеспечивают нас пищей, водой и кровом. И появляется все больше свидетельств того, что даже простое проведение времени на природе, в том числе занятия спортом на открытом воздухе, может значительно улучшить наше здоровье и благополучие.

Спорту тоже нужна природа. Будь то катание на лыжах, гребля на каноэ, пеший туризм или езда на велосипеде, занятия спортом зависят от здоровой окружающей среды.

Втожевремя, спортивныесооружения, такиекак футбольные стадионы и горнолыжные курорты, а также огромное количество зрителей на крупных спортивных мероприятиях, оказывают значительное влияние на окружающую среду. Спортивная индустрия несёт ответственность, наряду с заинтересованностью, за обеспечение устойчивости своей деятельности.

В этом руководстве МСОП «Спорт и биоразнообразие» подчёркивается, как спортивные федерации, местные организационные комитеты, инвесторы, спортсмены и болельщики могут помочь уменьшитьвоздействиеотраслинаокружающую среду. От восстановления деградированных земель до поддержки охраняемых территорий отрасль может внести свой вклад в сохранение и повысить осведомлённость зрителей о неоценимых преимуществах, предоставляемых природой.

Кроме того, коллективные действия отрасли могут способствовать глобальным усилиям по достижению целей, поставленных в Повестке дня Организации Объединённых Наций на период до 2030 года, в которой спорт признан «важным фактором устойчивого развития».

Данное руководство является первым из серии публикаций, которые будут выпущены в рамках партнёрства МСОП и Международного олимпийского комитета. В нём представлен обзор взаимосвязей между биоразнообразием и спортом для разработчиков спортивной инфраструктуры и организаторов мероприятий, а также описаны шаги, которые они могут предпринять для уменьшения негативного воздействия на природу, от планирования и строительства объектов, до фактических операций и наследия, которое они оставляют после себя. В руководстве также объясняется, почему игнорирование воздействия на биоразнообразие может создавать для отрасли ряд бизнес-рисков.

МСОП гордится тем, что объединился с Международным олимпийским комитетом. Мы надеемся на укрепление связей между спортивными и природоохранными сообществами для решения одной из самых важных задач нашего времени - защиты нашей планеты. Это гонка, которую мы не можем позволить себе проиграть.

Ингер Андерсен, Генеральный директор, Международный Союз охраны природы 


\section{Предисловие}

Спортивные соревнования проходят в самых разных средах, от морских и природных водноболотных угодий до городскихпарков, лесов, гор и даже пустынь. Во всех этих ситуациях спорт имеет прочную связь с биоразнообразием. Действительно, любое природное место или зелёное пространство, используемое для занятий спортом, будет иметь некоторое взаимодействие с биоразнообразием, и при тщательном управлении эти спортивные объекты потенциально могут быть ещё более ценными в качестве заповедников для многих видов диких растений и животных.

Спортивные парки в городских районах также могут поддерживать широкий спектр биоразнообразия, и они играют жизненно важную роль в качестве окружающих зелёных зон, предлагая общественные преимущества, выходящие за рамки их спортивной функции. Спортивные сооружения - стадионы и спортивные залы-могут быть частью инициатив по озеленению городов, от зелёных крыш и стен, до окружающих ландшафтов и дренажных систем. Некоторые спортивные сооружения в центре городов дошли до того, что обзавелись собственными площадками для выращивания экологически чистых продуктов и ульями.

Если смотреть не только на физический след спортивных площадок, то можно сказать, что отрасль спорта может оказывать значительное влияние на биоразнообразие через товары и материалы, которые она покупает, и выбросы парниковых газов от её повседневной деятельности.
Поэтому, независимо от конкретного контекста, мы считаем, что каждый в спортивном сообществе несёт важную обязанность заботы или патронажа об окружающей среде и защите биоразнообразия. Это часть нашей природы и жизненно важная часть того, что делает спорт таким особенным.

Поэтому MOK очень рад сформировать партнёрство с Международным союзом охраны природы (МСОП), ведущей мировой организацией по сохранению биоразнообразия. Наша общая цель - работать вместе, чтобы способствовать лучшему пониманию и защите биоразнообразия при помощи спорта.

Это руководство, подготовленное МСОП, является примером нашего партнёрства на практике. Оно даёт превосходный обзор синергии между спортом и биоразнообразием и является ценным дополнением $\mathrm{k}$ нашей собственной Стратегии устойчивого развития, вытекающей из Олимпийской повестки дня 2020, стратегической дорожной карты MOK.

Мы надеемся, что оно проинформирует и вдохновит всех в спортивном мире поближе взглянуть на то, как их занятия спортом взаимодействуют с окружающей средой и что они могут сделать для содействия сохранению биоразнообразия.

Кристоф де Кеппер, Генеральный директор, Международный олимпийский комитет 


\section{Основные факты и выводы}

Спорт может оказывать значительное негативное воздействие на биоразнообразие из-за строительства и использования спортивных объектов и проведения спортивных мероприятий. Это руководство предназначено для того, чтобы помочь лицам, принимающим решения, понять эти потенциальные воздействия и представить варианты их смягчения, а также максимально расширить возможности использования спорта как средства содействия и улучшения сохранения биоразнообразия.

Биологическое разнообразие, или, вкратце, биоразнообразие, определяется Конвенцией о биологическом разнообразии как «вариабельность живых организмов из всех источников, включая, среди прочего, наземные, морские и иные водные экосистемы, и экологические комплексы, частью которых они являются; это понятие включает в себя разнообразие в рамках вида, между видами и разнообразие экосистем».

Биоразнообразие поддерживает ценные экосистемные услуги, необходимые для выживания и здорового функционирования человеческого общества и его экономической деятельности. Однако, несмотря на это, деятельность человека ведёт к вызывающим тревогу и растущим темпам утраты биоразнообразия во всех экосистемах мира.

Спорт может негативно повлиять на биораз- нообразие из-за использования земель для строительства постоянных или временных спортивных объектов и сооружений, а также из-за загрязнения, шума, отходов, освещения, дорожного движения и потребности в ресурсах в результате проведения спортивных мероприятий, на которых присутствуют сотни или тысячи зрителей. В то же время, благодаря своему глобальному охвату, спорт может стать важным катализатором повышения осведомлённости о необходимости сохранения биоразнообразия, а также поощрения и поддержки усилий по увеличению биоразнообразия.

Понимание и управление потенциальными негативными воздействиями и возможностями сохранения жизненно важны для обеспечения успешной работы спортивных объектов и спортивных мероприятий как с финансовой, так и с операционной точек зрения. Неуправляемые или плохо управляемые воздействия на биоразнообразие могут привести к финансовым, нормативным, операционным и репутационным рискам. С другой стороны, своевременные и эффективные действия по снижению рисков и улучшению охраны окружающей среды могут помочь местам и организаторам мероприятий повысить их социальную лицензию на деятельность, упростить привлечение будущих спортивных мероприятий, установить долгосрочные позитивные отношения с сообществами и средствами массовой информации, а также привлечь спонсоров.

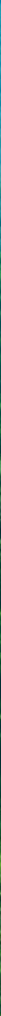




\section{Смягчение негативного воздействия на биоразнообразие}

Строительство новых спортивных объектов, установка временных объектов и связанных с ними объектов, а также использование и ремонт существующих объектов могут повлиять на биоразнообразие. Типы рисков и возможностей будут различаться, в основном, в зависимости от местоположения объекта (т.е. от того, находится ли он в городской зоне или в природной среде, и важности этой среды для биоразнообразия) и от его размера. Хотя воздействие может быть более широким, более серьёзным и более очевидным на природной, неосвоенной территории, где часто необходимо строить подъездные дороги, инфраструктуру электроснабжения, а также инфраструктуру водоснабжения и канализации (помимо прочего), существуют также риски для развития в городах, где многие виды живут в застроенной среде.

Проведение спортивных мероприятий как в городских, так и в природных условиях может повлиять на биоразнообразие из-за присутствия большого количества зрителей, которые увеличивают шум, ви- брацию, загрязнение, образование отходов и из-за движения транспорта. Другие риски для биоразнообразия, связанные со спортивными мероприятиями, Включают разливы нефти или топлива, сброс сточных вод, световое загрязнение, повышенное использование химикатов и удобрений и повышенный спрос на природные ресурсы.

Для устранения этих потенциальных воздействий, девелоперы должны в первую очередь соблюдать все юридические и законодательные требования, касающиеся биоразнообразия. Помимо соблюдения требований, рекомендуемый способ эффективного управления воздействиями на биоразнообразие - применение иерархии предотвращения, минимизации, восстановления и компенсации остаточных воздействий. Превентивные меры по смягчению последствий (предотвращение и минимизация) всегда предпочтительнее корректирующих мер (восстановление и компенсация).

\section{Максимальное расширение возможностей сохранения биоразнообразия}

Спортивные мероприятия и связанные с ними объекты могут использовать возможности для продвижения и поддержки сохранения биоразнообразия посредством различных мероприятий и инициатив, включая:

- улучшение естественной среды обитания в городской среде путём восстановления деградированных участков, соединения фрагментированных сред обитания, строительства «зелёных» крыш и живых стен, создания искусственных мест обитания для диких животных, увеличения разнообразия видов растений и включения насаждений в дизайн своих проектов, который обеспечивает дополнительную среду обитания и выгоды для местной фауны и фллорь

сти об управлении охраняемыми территориями путём проведения спортивных мероприятий с низким уровнем воздействия, таких как бег или катание на горных велосипедах, в пределах или частично в пределах охраняемых территорий;

- $\quad$ расширение имеющихся знаний и данных путём обмена кадастрами и базовой информацией биоразнообразия, которые могут быть востребованы природоохранными организациями и исследовательскими учреждениями как часть строительства объекта;

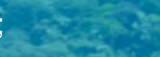

- создание выгод для биоразнообразия посред- ством проектов, направленных на компенсацию -. углеродного следа места проведения соревнований или мероприятия; охраняемой площади за счёт защиты пиродных өбъектов на территории или за её создание вығод для биоразнообразия посред-
пределами; - создание вығод для биоразнообразия носред

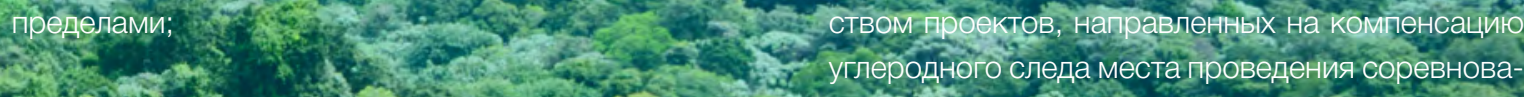
2. 6 создание фондов и повышение осведомлённо

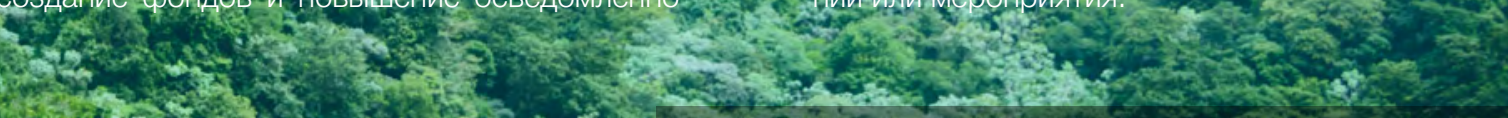

10.

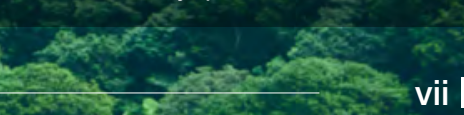




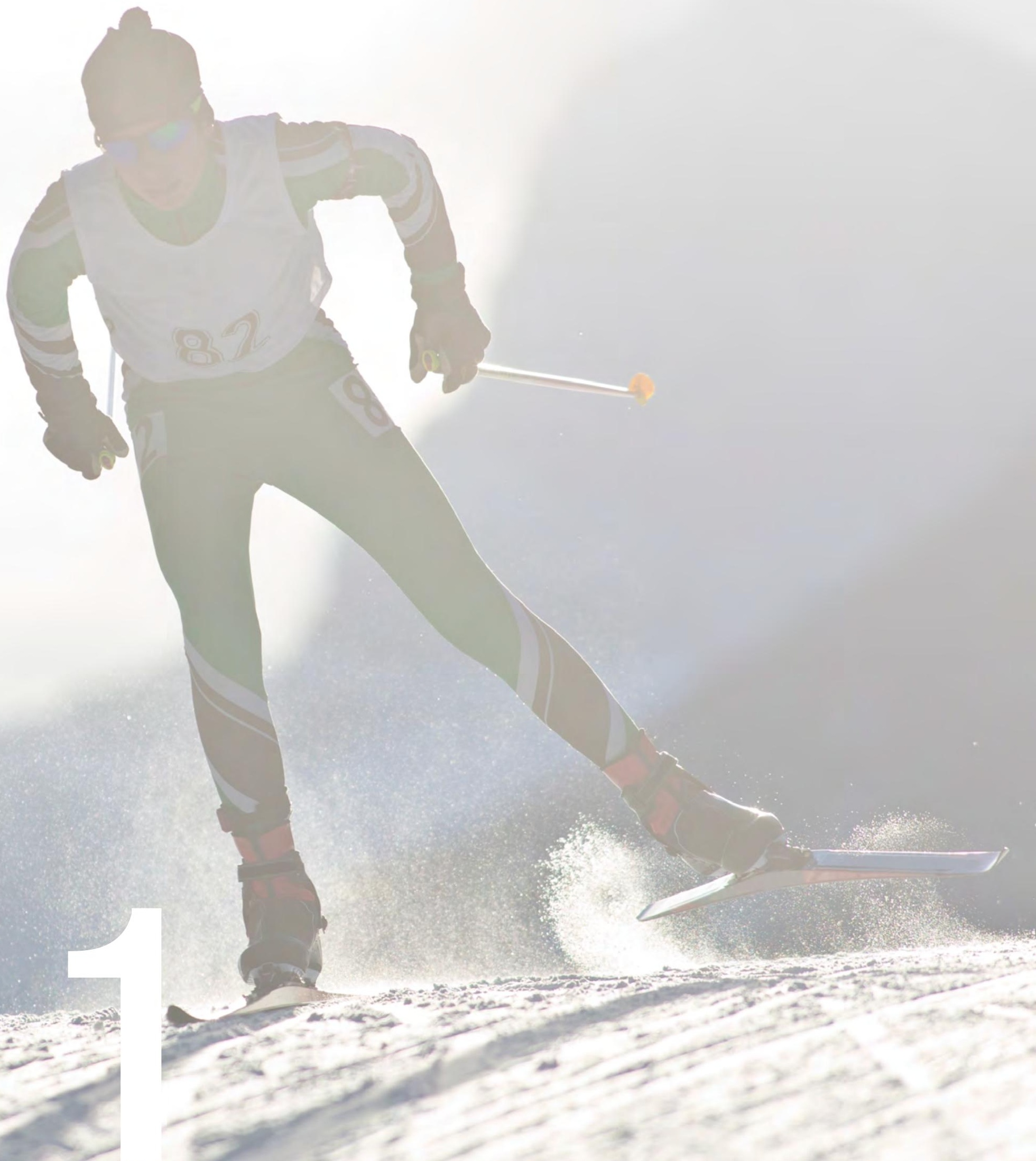

Гонщик на беговых лыжах (๐) iStock 


\section{1. Введение}

\section{1 Цели и область действия данного руководства}

Целями данного руководства являются:

- объяснение, что такое биоразнообразие и как на него может повлиять строительство спортивных объектов и проведение спортивных мероприятий;

- представление способов смягчения потенциальных негативных воздействий спорта на биоразнообразие;

- выделение особого внимания возможностям биоразнообразия, доступных спортивному сообществу.

Данное руководство было написано для всех связанных со спортом лиц, принимающих решения, от городских властей, играющих ключевую роль в развитии новых объектов и проведении торгов на спортивные мероприятия, до проектировщиков, архитекторов и инженеров, которым поручено выбрать место и дизайн строительства или реконструкции спортивных объектов; от владельцев/операторов площадок до региональных государственных чиновников; и от национальных и международных спортивных федераций до местных организационных комитетов (LOC), ответственных за планирование и проведение мероприятий.

Темы, представленные в данном руководстве, относятся к местным и международным мероприятиям, малым и крупным мероприятиям, видам спорта в помещении и на открытом воздухе, летним и зимним видам спорта, временной инфраструктуре, ремонту существующих объектов и строительству новых постоянных объектов.

\section{2 Биоразнообразие и экосистемы}

Биологическое разнообразие, или, вкратце, биоразнообразие, определяется Конвенцией о биологическом разнообразии как «вариабельность живых организмов из всех источников, включая, среди прочего, наземные, морские и иные водные экосистемы,
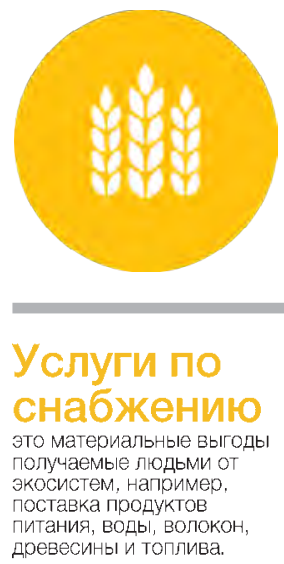

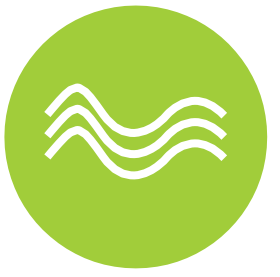

Регулирующие услуги

это выгоды, полученные от регулирования экосистемныХ процессов например, регупирование качества воздуха и плодородия почвы, борьба с наводнениями или опь пение сельскохозяйственных культур. и экологические комплексы, частью которых они являются; это понятие включает в себя разнообразие в рамках вида, между видами и разнообразие экосистем».
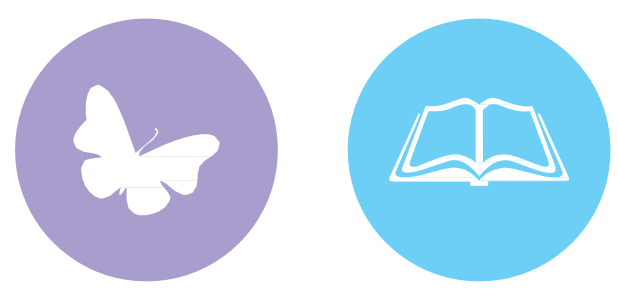

Вспомогатель-

ные услуги

необходимы для

производствавсех других

экосистемных услуг,

напоимер, за счёт

обеспечения растений и

животных Жизненными

пространствами,

позволяя разнообразие

видов и поддерживая

генетическое

разнообразие

\section{Культурные \\ услуги \\ нематериальные выгоды, \\ получаемые людьми от \\ экосистем, напоимер, \\ эстетическое и инженерное \\ вдохновение, культурная \\ благополучие.}

Рисунок 1: Биоразнообразие и поддерживающие жизнь биологические процессы (Источник: по материалам Оценки экосистем на пороге тысячелетия, 2005г. Экосистемы и благосостояние человека: обобщение и оперативная http://www.fao.org/ecosystem-services-biodiversity/en/ ) 
Утрата биоразнообразия происходит тревожными темпами в наземных, пресноводных и морских биомах мира. (см. Рисунок 2). Изменение климата, прямо или косвенно, также оказывает глубокое влияние на виды и среды их обитания. Растёт количество свидетельств того, что утрата генов, видов и экосистем ставит под угрозу предоставление жизненно важных услуг, предоставляемых биоразнообразием человеческим сообществам.

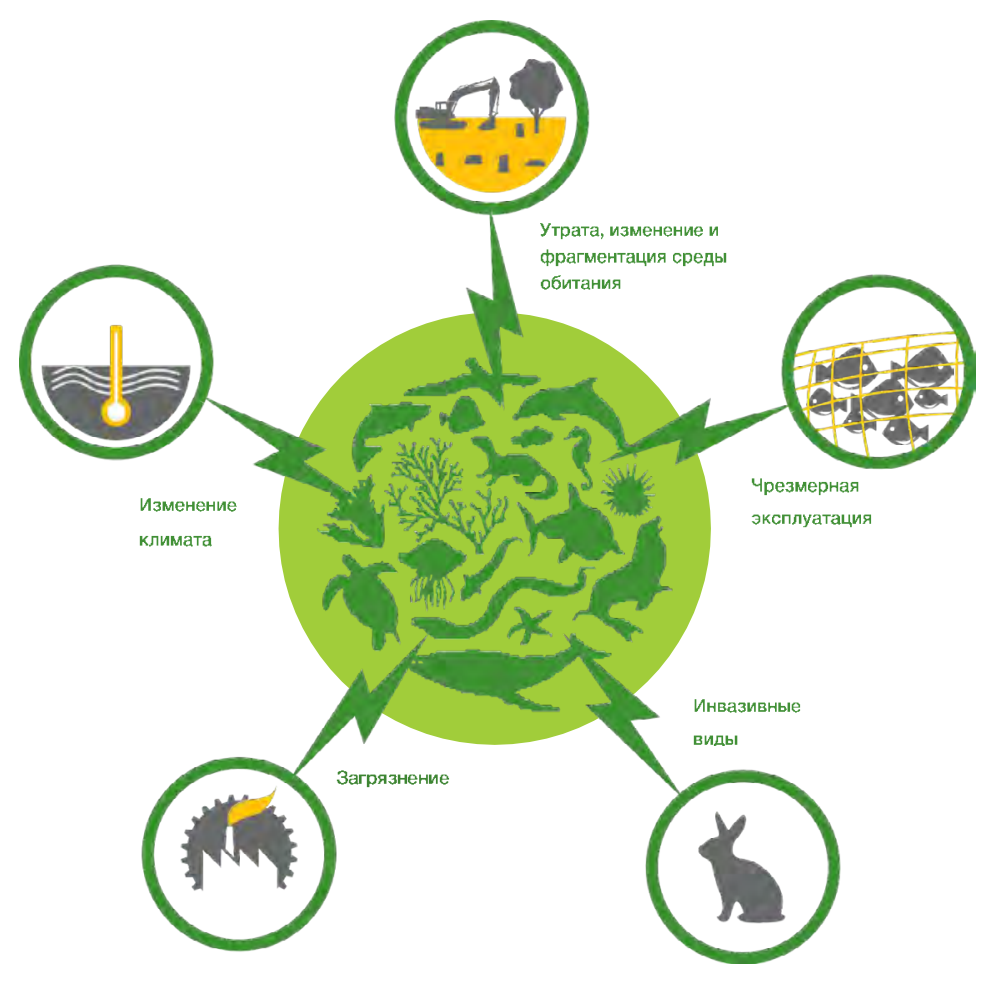

Рисунок 2: Прямое давление на биоразнообразие и экосистемы

(Источник: на основе Оценки экосистем на пороге тысячелетия, 2005 г. Экосистемы и благосостояние человека: синтез)

\section{3 Биоразнообразие и спорт}

Спорт может оказывать негативное воздействие на биоразнообразие из-за потребности земельных участков для строительства постоянных или временных спортивных объектов и вспомогательных сооружений. Дальнейшее неблагоприятное воздействие на биоразнообразие может возникнуть из-за спроса на природные ресурсы, такие как вода, образование большого количества твёрдых отходов и загрязнение вод, связанное с использованием химикатов и образованием городских сточных вод, а также изза высоких уровней шума и светового загрязнения, вызванных присутствием сотен и многих тысяч спортсменов, зрителей и средств массовой информации, особенно в природных зонах. Однако спорт, благодаря своей привлекательности для масс и постоянно растущему глобальному охвату, также может стать позитивным фактором сохранения биоразнообразия.

На различных этапах планирования объектов и проведения мероприятий (концепция, выбор площадки, проектирование и строительство, постановка, демонтаж, закрытие и перестройка объектов) могут приниматься решения по сохранению биоразнообразия за счёт как смягчения потенциальных негативных воздействий, так и усиления ресурсов биоразнообразия. Чтобы добиться успеха, крайне важно осознавать взаимосвязь между биоразнообразием и спортом и задавать правильные вопросы (см. Раздел 4) достаточно рано и постоянно, чтобы выявленные меры могли легче и эффективнее быть интегрированными во все фазы. 


\section{4 Экономическая модель для спорта и биоразнообразия}

Существует много причин для принятия своевременных мер для эффективного смягчения связанного со спортом воздействия на биоразнообразие, а также для максимального увеличения возможностей сохранения биоразнообразия. Неуправляемое или плохо управляемое воздействие на биоразнообразие может представлять ряд рисков для спортивного мероприятия, наиболее актуальными из которых являются:

- Финансовые риски: объект, который может негативно повлиять на биоразнообразие, может столкнуться с проблемами доступа к проектному финансированию. Кроме того, задержки строительства, связанные с конфликтами с местными сообществами и организациями гражданского общества из-за неэффективного управления ценностями биоразнообразия, также могут привести к значительным финансовым затратам для разработчиков и организационного комитета.

- Регуляторные риски: аспекты биоразнообразия играют центральную роль в процессах оценки воздействия на окружающую среду и экологическом лицензировании соответствующими органами. Кроме того, несоблюдение местных правил может привести к большим штрафам.

- Операционные риски: недостаточно защищённая или управляемая среда может поставить под угрозу здоровье спортсменов и снизить привлекательность мероприятий и мест проведения мероприятий для местного населения, зрителей и средств массовой информации.

- Репутационные риски: плохо управляемое воздействие на биоразнообразие может привести к критике и кампаниям со стороны средств массовой информации и гражданского общества. Это может повлиять на мероприятие из-за более низкой посещаемости, трудностей с получением корпоративного спонсорства и восприятия негативной связи между проблемой биоразнообразия и мероприятием/спортивной федерацией.
С другой стороны, принятие своевременных и эффективных мер по смягчению негативных воздействий и максимальному использованию возможностей сохранения может привести к:

- $\quad$ более простому и быстрому доступу к проектному финансированию и получение необходимых разрешений для планирования и охраны окружающей среды;

- повышению привлекательности региона, города, места проведения или федерации для будущих спортивных мероприятий, благодаря национальному или международному признанию передовой практики в этом секторе;

- у установлению долгосрочного позитивного взаимодействия с организациями гражданского общества, местными сообществами и средствами массовой информации, что может принести пользу спортивной отрасли в целом и, в частности, успешной организации мероприятия;

- получению социальной лицензии на ведение деятельности путём устранения озабоченностей гражданского общества по поводу воздействия места проведения и спортивных мероприятий на биоразнообразие;

- привлечению спонсоров, стремящихся продвигать экологически чистые продукты или желающих связать свой имидж с окружающей средой и биоразнообразием;

- $\quad$ содействию устойчивым городам и здоровому образу жизни;

- $\quad$ работе по достижению Целей устойчивого развития, в частности, Цели 14 «Жизнь под водой» и Цели 15 «Жизнь на суше», а также Целей Айти в области биоразнообразия Конвенции о биологическом разнообразии. 


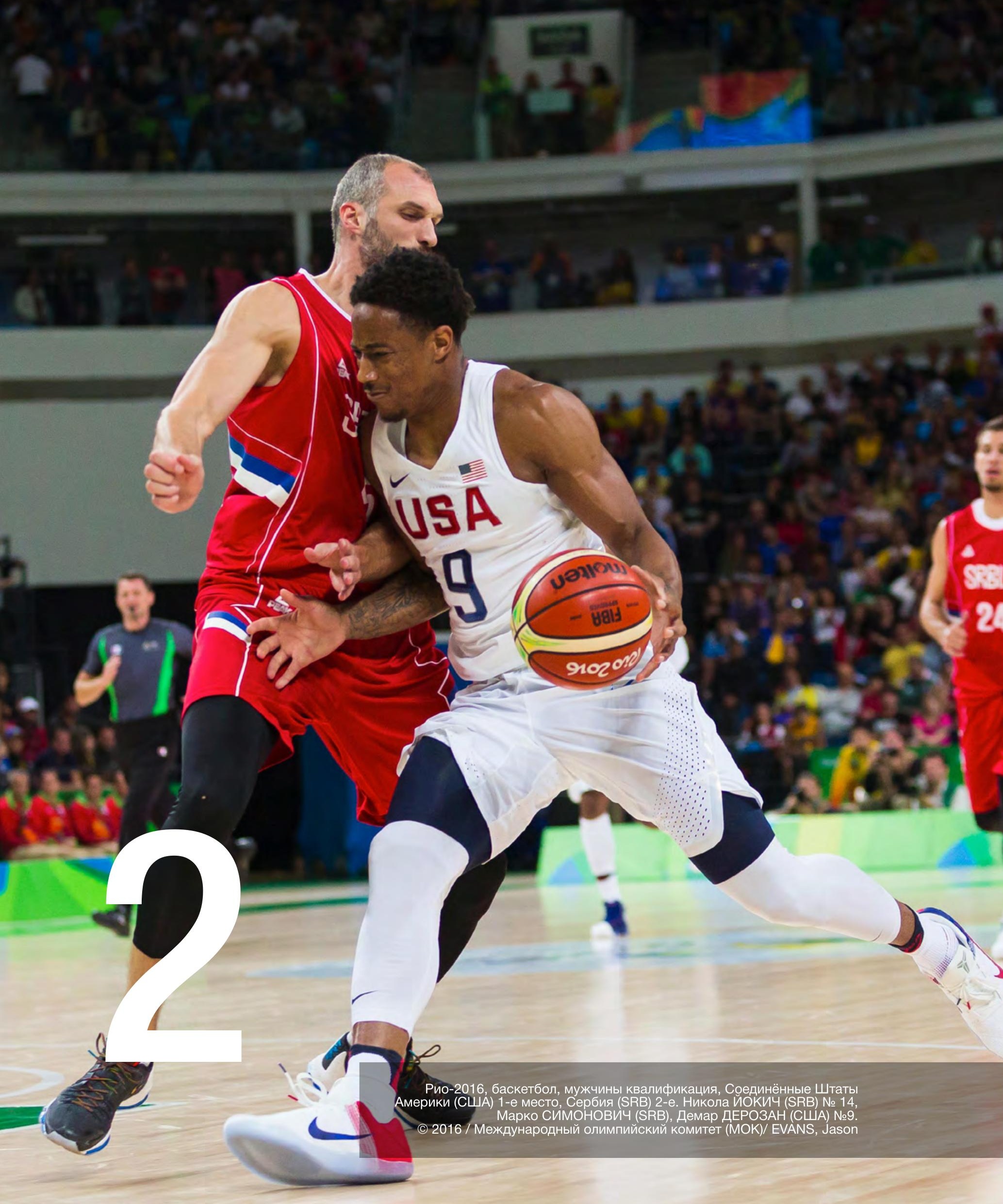




\section{2. Управление воздействием спортивных объектов и спортивных мероприятий на биоразнообразие}

\section{1 Общее описание}

Утрата биоразнообразия, то есть сокращение разнообразия растений и животных (на генетическом, видовом и экосистемном уровнях), может быть вызвана:

- деградацией, фрагментацией и утратой сред обитания;

- интродукцией инвазивных видов;

- $\quad$ загрязнением;

- изменением климата;

- чрезмерной эксплуатацией природных ресурсов.
Строительство новых спортивных объектов и вспомогательной инфраструктуры, такой как подъездные пути и линии электропередач; установка временных площадок и связанных с ними объектов, включая парковки, зрительские эстакады, временные сидения, общественные туалеты, смотровые площадки, ограждения, коммуникационную инфраструктуру, торговые точки и т.д.; а также проведение спортивных мероприятий, всё это может прямо или косвенно способствовать этим давлениям.

\section{2 Воздействия, связанные со спортивными объектами}

Расположение и размер места проведения соревнований будут определять тип рисков, а также возможности, с которыми придётся столкнуться. Спортивные объекты могут быть расположены в городской или природной среде, главное отличие состоит в том, что городская среда с точки зрения биоразнообразия обычно рассматривается как в значительной степени «изменённая среда обитания», в то время как природная среда обычно квалифицируется как «естественные места обитания» или «критические места обитания» (см. Вставку 1).

Природные среды обитания обычно более чувствительны, чем изменённые среды обитания, к измене-

\section{Вставка 1. Изменённые, природные, критические места обитания... В чем разница?}

Изменённые места обитания - это «районы, которые могут содержать значительную долю видов растений и животных неместного происхождения, и где деятельность человека существенно изменила основные экологические функции и состав видов районов». С другой стороны, природные места обитания определяются как «районы, состоящие из жизнеспособных сообществ видов растений и животных, в основном местного происхождения, и где деятельность человека не повлияла существенно на основные экологические функции и состав видов района». Критические места обитания представляют собой подмножество природных или изменённых местообитаний и определяются как «... области планеты с высоким значением сохранения биоразнообразия на основе существования мест обитания, имеющих большое значение для видов, находящихся под критической угрозой исчезновения или под угрозой исчезновения, видов ограниченного ареала или эндемичных видов, глобально значимых скоплений мигрирующих и стайных видов, находящихся под большой угрозой исчезновения и уникальных экосистем и ключевых эволюционных процессов».

Источник: Стандарт деятельности Международной финансовой корпорации 6, 2012г. 
ниям, связанным со строительством новых объектов, особенно когда речь идёт о большой площади участков и строительстве крупных и сложных объектов. Критические среды обитания, учитывая их значение для сохранения биоразнообразия, вероятно, будут наиболее чувствительны к этим изменениям. С другой стороны, спортивные объекты на сильно изменённых территориях могут иметь возможность восстановления деградированных территорий в рамках своего развития. Как правило, размер нового объекта определяет уровень воздействия в конкретной окружающей среде, в то время как использование существующих объектов позволяет избежать связанных с землепользованием воздействий строительства нового объекта.

Когда новые объекты, постоянные или временные и связанная с ними инфраструктура, создаются в природных или критических местах обитания, они могут способствовать деградации, фрагментации и утрате мест обитания, особенно если они занимают большую площадь. Масштабы этого воздействия также будут в значительной степени зависеть от ценности биоразнообразия даннойие спортивных объектов на территории или в непосредственной близости от морских, прибрежных и наземных охраняемых территорий, ключевых районов биоразнообразия, объектов всемирного наследия, Рамсарских угодий, или важных территорий для птиц и биоразнообразия будет сопряжено с высокими рисками для биоразнообразия. Хотя природная среда обитания может не иметь специального назначения, она наверняка будет иметь большое разнообразие видов растений и животных, которые могут быть затронуты. Также важно понимать, что, в определённых ситуациях, даже если прямое воздействие объекта на биоразнообразие минимально, оно может ухудшить и без того критическую ситуацию. Новые спортивные объекты, включая ряд объектов инфраструктуры, та- ких как подъездные дороги, линии электропередач и трубопроводы, необходимые для их поддержки, также могут фрагментировать среду обитания и природные коридоры на местности. Эти воздействия увеличивают воздействие на экологические следы и могут привести к кумулятивному негативному воздействию, которое сделает невозможным сохранение природного сообщества, среды обитания или вида.

Когда спортивные объекты создаются в изменённой среде, например, в городских условиях, на первый взгляд может показаться, что нет никакого риска для биоразнообразия, поскольку не ожидается, что здания и построенные объекты предоставят укрытие большому количеству видов дикой природы. Однако городские районы с их разнообразием застройки являются важными средами обитания для широкого круга видов, использующих стены, мосты, крыши и другие части построек и сооружений для ночлега, гнездования, размножения и колонизации. Летучие мыши, птицы, лишайники, мхи, полевые цветы, а также многие млекопитающие и беспозвоночные называют городские постройки «домом». Нарушения в этих местах из-за сноса старых зданий, чтобы освободить место для новой инфраструктуры; ремонт существующих зданий; установка временной инфраструктуры, необходимой для проведения мероприятий; усиленное освещение, вибрация и пыль; или другие физические изменения их местообитаний могут оказать значительное влияние на городские виды растений и животных. Это, в сочетании с общим отсутствием признания и информации об аспектах биоразнообразия в городской среде, означает, что управление биоразнообразием в этих областях часто не является частью проектного планирования. Следовательно, воздействия часто бывают неизвестными и непреднамеренными.

\section{3 Воздействия, связанные с организацией спортивных мероприятий}

Спортивные мероприятия, проводимые на городских площадках или в природных ландшафтах, могут негативно повлиять на биоразнообразие из-за большого количества зрителей, увеличивающих шум, вибрацию и освещение, производящих большое количество твёрдых отходов и сточных вод и создающих транспортное движение, которое может увеличить загрязнение и смерти представителей дикой природы на дорогах. Кроме того, открытые площадки в городских районах или рядом с ними, используемые для отдыха и досуга, часто представляют собой легко обслуживаемые среды.

При организации спортивного мероприятия может наблюдаться значительное увеличение управленческой деятельности, например, усиление стрижки травы, кустов, зарослей или бордюров. Удаление этой растительности (например, скошенной травы, опавших 
листьев, мёртвой древесины) может нарушить или уничтожить среды обитания биоразнообразия. Применение химических удобрений, пестицидов и мер борьбы с комарами может ещё больше повлиять, уменьшить или ограничить возможности выживания видов в этих интенсивно управляемых средах.

Риски для биоразнообразия, связанные как с летними, так и с зимними спортивными мероприятиями, проводимыми на открытом воздухе в природной среде, происходят из многих источников, включая разли- вы нести или топлива; образование твёрдых отходов; использование чистящих средств, пестицидов или гербицидов; сброс сточных вод в воду или на сушу; интродукцию инвазивных видов; шум, освещение и вибрация; дорожно-транспортные происшествия и убийства на дорогах; и необходимость, даже временно, возвести ограждения и коммуникационную инфраструктуру, а также расширить и построить новые зоны старта и финиша, смотровые площадки, медиа-пункты, медицинские станции, заправочные станции, торговые точки для обслуживания мероприятия

\section{Вставка 2: Политика МСОП по компенсации биоразнообразия}

Политика МСОП по компенсации воздействия на биоразнообразие 2016 года подчёркивает ряд основополагающих принципов, которые следует принимать во внимание для эффективного внедрения иерархии смягчения воздействий. Эти принципы включают:

1. Применение иерархии как можно раньше в жизненном цикле проекта, чтобы информировать о потенциальных строительных решениях.

2. Подробное рассмотрение проекта в более широком контексте ландшафта суши или морского пейзажа.

3. Выявление и уважение признанных на национальном и международном уровнях запретных областей. 4. Изучение альтернативы с меньшим воздействием при дизайне проекта, включая отказ от проекта вообще, признавая, что не все воздействия могут быть компенсированы без чистых убытков. 5. Уделение первостепенного внимания предотвращению любого ущерба биоразнообразию. 6. Полный учёт прямых, косвенных и кумулятивных воздействий, как географически, так и с течением времени.

7. Чёткое разделение компенсаций и мер по предотвращению, минимизации и восстановлению на месте.

8. Разработку компенсационных мер таким образом, чтобы обеспечить, по крайней мере, отсутствие чистых потерь и, предпочтительно, чистый прирост биоразнообразия.

9. Обеспечение, чтобы любые компенсации биоразнообразия, используемые как часть иерархии смягчения воздействий, обеспечивали дополнительные результаты сохранения, которых не было бы в противном случае.

10. Использование научно обоснованных, прозрачных и основанных на широком участии подходов, учитывающих влияние проекта и действий по смягчению последствий на средства существования. 11. Следование подходу, основанному на правах человека, как это определено в резолюции МСОП WCC-2012-Res-099.

12. Определение и внедрение правовых, институциональных и финансовых мер, необходимых для обеспечения долгосрочного управления всеми действиями по смягчению последствий (включая любые компенсации биоразнообразия).

13. Применение строгой системы мониторинга, оценки и правоприменения, включающей независимую проверку всех действий по смягчению последствий.

14. Применение принципа предосторожности на всех этапах иерархии смягчения последствий.

15. Применение экосистемного подхода на всех этапах иерархии смягчения последствий.

Политика МСОП также признаёт, что существуют ограничения на компенсацию биоразнообразия, и что «при определённых обстоятельствах остаточные воздействия на биоразнообразие (после завершения этапов иерархии смягчения последствий: предотвращения, минимизации и восстановления) не могут быть компенсированы. Кроме того, есть некоторые компоненты биоразнообразия, для которых воздействие теоретически можно компенсировать, но с высоким риском неудачи. В этих обстоятельствах компенсации биоразнообразия неуместны, а это означает, что проект в том виде, в котором он был разработан, не должен продолжаться».

Источник: вебсайт МСОП 


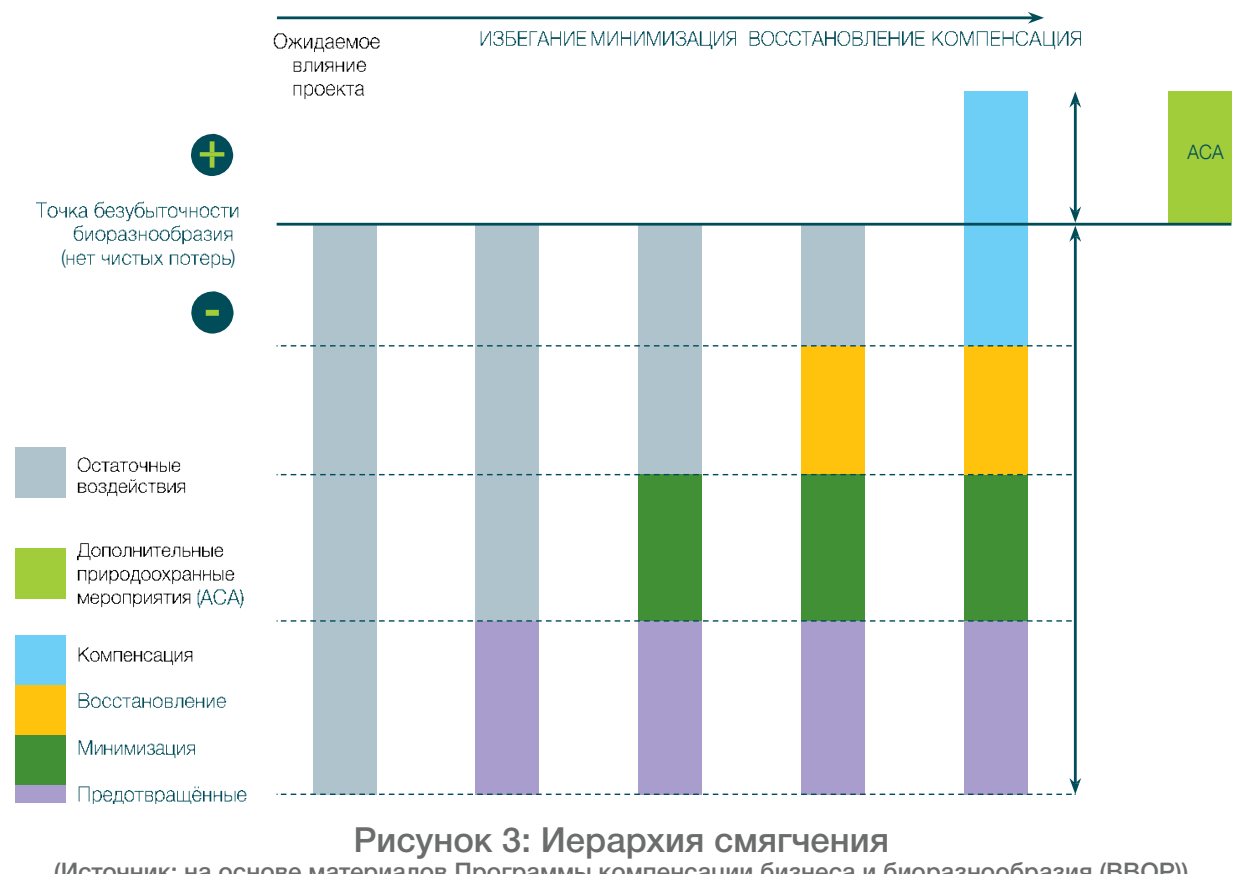

и водохранилища для искусственного оснежения.

и велосипедов там, где это не разрешено - всё это может иметь негативное воздействие на биоразнообразие, напри-

Зрители также могут нанести ущерб природным средам мер, мешать размножению, гнездованию и кормлению животных. Такое поведение в хрупких открытых пространствах может негативно, а в некоторых случаях и необратимо, повлиять как на биоразнообразие, так и на среды обитания.

\section{4 Смягчение воздействий на биоразнообразие}

В большинстве стран экологические нормы регулируют строительство новых спортивных объектов или расширение и модисикацию существующих объектов. В данном руководстве эта тема не рассматривается, за исключением того, что спортивные организаторы должны соблюдать все юридические требования, касающиеся биоразнообразия.

В рамках и за пределами соблюдения правовых норм рекомендуемым способом эффективного управления воздействиями на биоразнообразие является так называемая «иерархия смягчения последствий», включающая предотвращение, минимизацию, восстановление и компенсацию (см. Рисунок 3 и Вставку 2). Иерархия смягчения последствий включает последовательность действий по устранению негативных воздействий на биоразнообразие. В соответствии с иерархией смягчения последствий, по возможности, воздействий следует избегать. Там, где их избежать невозможно, воздействия следует свести к минимуму. Затем эти воздействия следует смягчить посредством восстановительных действий, а там, где всё ещё сохраняются значительные остаточные воздействия, следует осуществить компенсацию биоразнообразия. Меры по смягчению последствий, которые предотвращают, а затем минимизируют воздействия, имеют приоритет над мерами по исправлению или устранению воздействий, учитывая риски, связанные с восстановлением и компенсациями. По этой причине следует проявлять особую осторожность при выборе подходящего места для нового спортивного объекта или спортивного мероприятия. Рассмотрение в качестве таких мест изменённых или деградированных участков даёт значительные выгоды: риски негативного воздействия на биоразнообразие невелики, а возможности принести пользу сохранению биоразнообразия огромны. Целью всех мер по смягчению воздействия может быть поставлено либо на «отсутствие чистых убытков», либо, что ещё лучше, «чистая прибыль» биоразнообразия.

Наконец, важно вовлечь специалиста-эколога в команду по планированию новых спортивных объектов и спортивных мероприятий на ранней стадии, чтобы помочь выявить риски для биоразнообразия и потенциальные значительные воздействия, которые необходимо будет смягчить. Невыполнение этого требования может привести к задержкам и, в конечном итоге, к дополнительным расходам. 



\section{3. Максимальное расширение возможностей сохранения биоразнообразия}

Спортивные мероприятия и связанные с ними объекты, включая подъездные дороги, парковки и т.д., могут способствовать сохранению биоразнообразия на местном и глобальном уровне. Выявление этих возможностей может помочь укрепить отношения между застройщиками пло- щадок и организаторами мероприятий, а также местными сообществами. Хотя окончательного списка возможностей не существует, в этом разделе обсуждаются некоторые доступные варианты.

\section{1 Улучшение, восстановление и воссоединение естественных сред обитания в городской среде}

Любое спортивное мероприятие может привести к благоустройству или обновлению города путём восстановления деградированных участков, соединения природных участков и мест обитания, которые со временем могли стать фрагментированными, строительства «зелёных» крыш и живых стен, а также создания искусственных мест обитания, подходящих для использования животными, такими как как птицы и летучие мыши.

Строительство новых постоянных площадок может дать возможность вернуться к использованию существующей деградированной территории, такой как бывшие свалки или заброшенные промышленные районы, вместо развития «зелёной зоны» (см. Вставку 3). Использование деградированных земель в качестве площадки для нескольких новых объектов было центральной частью стратегии Олимпийских игр в Сиднее в 2000 году Олимпийских игр в Лондоне в 2012 году и кандидатуры Парижа на проведение Олимпийских игр в 2024 году. Посредством такого процесса трансформации организаторы могут помочь обратить вспять существовавшие ранее тенденции, наносившие ущерб городскому биоразнообразию и средам обитания. Спортивные мероприятия также могут дать возможность развивать городские экологические коридоры; у этих открытых пространств есть потенциал для многократного использования городских жителей.

Существует много других вариантов улучшения среды обитания в городских пространствах, например, включение насаждений, привлекающих опылителей и насекомых, питающихся нектаром, и добавление укрытий для птиц, летучих мышей и беспозвоночных (см. Вставку 4). Вдоль дорог можно

\section{Вставка 3. Соревнования по гольфу восстанавливают промышленные площадки и местные виды}

В Рио-де-Жанейро потребовалось предвидение, чтобы взглянуть на деградировавший старый карьер, на 80\% покрытый нетронутой растительностью, и увидеть потенциал его преобразования в природное поле для гольфа с защитой и улучшением биоразнообразия в основе его дизайна. И именно это и произошло на Олимпийских играх в Рио-де-Жанейро в 2016 году, когда неиспользуемый карьер превратился в «натурализованное» поле для гольфа. Преобразование привело к увеличению растительного покрова на 167\% и чистому увеличению биоразнообразия со 118 видов, обнаруженных на территории до начала проекта, до 263 видов после этого. Это место было быстро заселено редкими и охраняемыми видами, в том числе роющими совами, кайманами, капибарами, чибисами, куликами и цаплями. Чтобы достичь этого состояния, более 15000 местных растений были пересажены в этот район, и на территории был создан питомник для выращивания более 475000 растений из местных семян для заселения участка.

Источник: Julie Duffus (интервью, июль 2017), Организационный комитет олимпийских и паралимпийских игр Рио 2016г. 


\section{Вставка 4. Спорт, ведущий к возрождению устриц в проливе Солент}

Когда команда яхтсменов Land Rover BAR начала строить свой новый дом на набережной в Портсмуте, команда определила угрозу для природной экосистемы прямо у порога. Солент, пролив, отделяющий материковую Англию от острова Уайт, когда-то поддерживал торговлю устрицами на миллионы фунтов стерлингов. Однако в последние несколько лет резкое сокращение местной популяции устриц привело к последующему краху промысла устриц в этом районе.

Имея возможность реально повлиять на экосистему прямо у порога, команда была рада помочь изменить мир к лучшему. Идея была проста: работая со своими партнёрами, они должны были вырастить взрослые устрицы в защищённых клетках на базе команды, повторить это на понтонах для дальнейшего воспроизводства и «засеять» более широкий промысел.

Теперь установлены клетки для устриц, и устрицы успешно вернулись в гавань. Д-р Джоан Престон из Института морских наук Портсмутского университета прокомментировала: «Замечательно видеть завершение первого этапа. Устрицы уже внутри, поэтому теперь мы можем начать сбор данных, чтобы лучше понять, что происходит с устрицами и окружающей их экосистемой».

Источник: LandRover BAR

сажать деревья, чтобы стимулировать биоразнообразие в искусственной среде. Богатые видами газоны, декоративные деревья и кустарники могут быть созданы с использованием местных видов вместе с растениями, приносящими пользу местной фауне и флоре в других местах. Водно-болотные угодья могут быть восстановлены на территориях, где они ранее могли быть осушены, с использованием дренажных систем и посадки тростниковых зарослей и других местных растений, соответствующих местным условиям.

Увеличение разнообразия видов растений, трав и деревьев может увеличить богатство среды обитания. Например, низкорослые полевые цветы можно посадить в зелёное поле, чтобы увеличить разнообразие видов; среда обитания луга может быть создана вокруг границ футбольного, хоккейного полей или теннисных кортов; а здания могут быть частич- но или полностью покрыты растительностью для создания живых «зелёных» крыш и стен. Вместо фонтана можно построить пруды; тростниковые заросли могут быть внесены в водоём для очистки воды и привлечения биоразнообразия; или вместо цементных стен и заборов можно использовать бревенчатые стены, чтобы принести пользу насекомым и другим беспозвоночным. Всё это варианты, которые могут служить целям организаторов мероприятий, в то же время улучшая городскую среду и обеспечивая биоразнообразие, а также эстетические преимущества.

Существует множество преимуществ работы с местными природоохранными организациями, которые могут предоставить ценный вклад в знания о местном биоразнообразии, предложить советы и рекомендации по смягчению последствий и взять на себя руководство реализацией проектов по

\section{Вставка 5: Повторное использование спортивного инвентаря для сохранения биоразнообразия}

Начиная с 2001 года федерация Wildlife Trusts и Уимблдонский теннисный турнир работают вместе, чтобы не дать ему стать «игрой, сетом и матчем» для самого маленького млекопитающего Великобритании, мыши-малютки (Micromys minutus). Около 36000 теннисных мячей, использованных на всемирно известном турнире, ежегодно перерабатываются в качестве домов для мышей-малюток, чтобы помочь защитить исчезающий вид от многочисленных хищников и от утраты их среды обитания из-за интенсивного земледелия.

Теннисные мячи с небольшим отверстием в стенке превращаются в отличные водонепроницаемые дома. Они прикреплены к шестам на высоте около метра от земли, где мыши могут вить гнезда вдали от хищных птиц и наземных хищников.

Теперь, помимо Уимблдона, многие клубы большого тенниса по всему Соединённому Королевству регулярно жертвуют использованные теннисные мячи местным организациям, занимающимся дикой природой, чтобы помочь им в их усилиях по сохранению.

Источник: Julie Duffus (интервью, июль 2017г.), Организационный комитет олимпийских и паралимпийских игр в Лондоне (LOCOG) 
сохранению (см. Вставку 5). В идеале с этими организациями следует связываться на ранней стадии планирования, чтобы их вклад мог помочь в формировании дизайна спор- тивных объектов, а не позже, когда ущерб, возможно, уже был нанесён.

\section{2 Увеличение охраняемой территории}

Спорт и спортивные мероприятия могут привести к увеличению количества охраняемых территорий, либо путём содействия расширению существующих охраняемых территорий, либо путём создания новых охраняемых территорий. Это увеличение может происходить в результате иерархии смягчения воздействий, если установлена компенсация биоразнообразия, или за счёт защиты на месте. Защита территории и управление ею в качестве компенсации биоразнообразия предоставляют возможности для обеспечения долгосрочной связи между мероприятием и вновь созданной охраняемой территорией, а также создают положительную рекламу для застройщика или спортивной организации. Взносы в финансирование текущего управления могут быть получены за счёт использования процента от вступительных взносов на объект или посредством соглашений о коммерческом спонсорстве.
Возможности увеличения количества охраняемых территорий на местах могут возникнуть, если в процессе планирования будут определены важные места обитания, а затем они будут официально защищены в рамках развития мероприятия. Например, создание в Афинах в 2004 году Олимпийского центра гребли предоставило городу возможность восстановить сильно деградировавшие водно-болотные угодья (см. Вставку 6). Местный организационный комитет успешно работал с Министерством общественных работ над удалением небольшого аэропорта, восстановлением заболоченных земель и прилегающих лесных территорий, а также проектированием и развитием объекта как природного, а не искусственного озера.

\section{Вставка 6. Восстановление водно-болотных угодий: от деградированного участка к гребному центру и национальному парку}

Деградированное заболоченное место у побережья на окраине Афин было выбрано в качестве идеального места для создания гребного центра для Олимпийских игр 2004 года. Однако многочисленные антропогенные нагрузки привели к значительной деградации окружающей среды до такой степени, что возник высокий риск исчезновения эндемичных пресноводных рыб и редких видов растений в этом районе.

На этапе планирования среда обитания и проект рассматривались как единая система, которая изучалась с экологической, территориальной и социально-синансовой точек зрения. Целью было оптимизировать дизайн и работу проекта по отношению к среде обитания, одновременно определяя меры и вмешательства для улучшения экологических функций и защиты среды обитания.

Окончательная компоновка гребного центра учитывала все эти параметры, а также отвечала спортивным требованиям, установленным международными стандартами. Чувствительный баланс грунтовых вод, двух недавно построенных полу-природных озёр, заболоченной территории и ухода за песчаными дюнами соснового леса занимали видное место в дизайне. Вся территория, включая гребной центр, была с тех пор обозначена как национальный парк Шинейс, чтобы способствовать защите окружающей среды, а также отдыху и занятиям спортом. Этот случай является наглядным примером того, как улучшение биоразнообразия может сосуществовать со спортом и обеспечивать долгосрочные положительные выгоды для всех.

Источник: George Kazantzopoulos (интервью, июль 2017г.), Асринский организационный комитет игр (ATHOC) 2004Г. 


\section{3 Создание фондов для финансирования управления охраняемыми территориями}

\begin{abstract}
Спортивные мероприятия с низким уровнем воздействия на природных ландшастах, такие как бег и катание на горных велосипедах, предлагают реальные возможности для маркетинга и привлечения финансирования для сохранения окружающей среды за счёт наглядности и воздействия, создаваемого мероприятием.
\end{abstract}

Благодаря своей природной красоте, чистой воде и чистому воздуху, охраняемые территории предлагают привлекательные условия для проведения спортивных мероприятий с низким уровнем воздействия. В зависимости от местоположения, типа среды обитания, размера мероприятия и существующей инфраструктуры или возможности создания вре- менной инфраструктуры с низким уровнем воздействия, спорт и биоразнообразие могут быть совместимы, и мероприятие может поддержать основную цель охраняемой территории, обеспечение сохранения биоразнообразия.

Поскольку мероприятие должно соответствовать действующему законодательству о защите и зонированию конкретной охраняемой территории, соответствующие мероприятия почти всегда будут носить временный характер, без постоянных спортивных объектов или другой специальной спортивной инфраструктуры, созданной внутри охраняемых территорий.

\section{4 Повышение осведомлённости общественности о биоразнообразии}

Спортивные мероприятия могут стать платформой для повышения осведомлённости местного населения о важно- сти биоразнообразия и сохранения биоразнообразия (см. Вставки 7 и 8). Они также могут повысить глобальную ос-

\section{Вставка 7: Езда на велосипеде по живописной местности}

Бокс-Хилл - это особый заповедник (SAC) и участок особого научного интереса (SSSI) на юге Англии. В этом районе обитает несколько видов растений и животных, находящихся под угрозой исчезновения в стране, в том числе два культовых вида - голубая бабочка Адонис и орешниковая соня, а также их источники пищи.

Этот район был частью маршрута London Surrey Cycle Classic и велосипедных шоссейных гонок Олимпийских игр 2012 года в Лондоне. Во время планирования было определено, что зрители на велосипедном маршруте будут одним из основных источников потенциального воздействия на объект.

Экологические исследования, проведённые с партнёрами, помогли определить чувствительность видов, создали новые знания о видах и их пищевых растениях, а также предоставили информацию для планирования наблюдения за зрителями, а также для обучения на открытом воздухе и занятий экологическим искусством для повышения осведомлённости зрителей. Эти мероприятия включали создание фильмов, проекты по созданию боксов для зимней спячки орешниковой сони и другие инициативы, призванные помочь зрителям понять любые ограничения на просмотр гонки и познакомить их с природными качествами места проведения спортивного мероприятия.

Источник: Julie Duffus (интервью, июль 2017г.), Организационный комитет олимпийских и паралимпийских игр в Лондоне (LOCOG) 


\section{Вставка 8: Плавание для сохранения экосистемы}

Два инвазивных вида крылаток (Pterois volitans и Pterois miles) представляют растущую угрозу для атлантических и карибских рифов. Считается, что эта рыба, обитающая в Индо-Тихоокеанском регионе, была впервые завезена вдоль юго-восточного побережья Флориды в 1980-х годах. С тех пор рыба быстро распространилась на север и юг и теперь встречается на севере до Каролины и по всему Карибскому региону. Теперь они начинают вторжение в Мексиканский залив и северное побережье Южной Америки. Везде, где они распространяются, крылатки представляют серьёзную угрозу для местных рифовых рыб и экосистем коралловых рифов.

Поскольку вокруг Багамских островов нет природных хищников, популяции крылаток резко увеличились, и в некоторых районах уничтожили экосистему рифов, что привело к краху рыбной промышленности и нанесению значительного ущерба индустрии туризма.

В попытке контроля этих инвазивных видов, местные сообщества на багамском острове Элеутера используют спорт для просвещения и повышения осведомлённости. Ежегодное мероприятие по плаванию, в котором участники соревнуются, чтобы поймать как можно больше крылаток, объединяет спорт и охрану, чтобы не только уменьшить количество крылаток на рифах, но и рассказать людям о важности сохранения рифов для будущих поколений.

Затем мероприятие идёт ещё дальше, проводя кулинарный урок для всех спортсменов и зрителей, чтобы члены местного сообщества могли научиться готовить и есть рыбу в надежде, что местные рыбаки начнут ловить эту разрушительную инвазивную крылатку.

Источник: Cape Eleuthera Institute (web)

ведомлённость, когда мероприятие принимает зрителей со всего мира. Благодаря множеству доступных в настоящее время медиа-платформ спортивные мероприятия являются мощным катализатором осведомлённости общественности и дают возможность привлечь внимание широкой аудитории к вопросам, связанным с биоразнообразием.

Важно, чтобы сообщения о биоразнообразии имели отношение к конкретному виду спорта, спортивному мероприятию или зрительской аудитории. Сообщения должны быть о биоразнообразии и связанных с ним угрозах, а также о связи с другими проблемами устойчивости, такими как здоровый образ жизни, с целью создания поддержки или изменения поведения и связанных с ними воздействий. Именно здесь может быть полезным партнёрство с местными природоохранными организациями и группами активистов.

Использование элементов биоразнообразия, представленных в виде талисманов, включённых в билеты на мероприятия или унисорму сотрудников, или как части логотипа мероприятия, может иметь мощное воздействие, если связано с правильным сообщением. Однако важно отметить, что выбранные элементы должны быть связаны с фактическим местом проведения мероприятия или с его окрестностями, чтобы было можно разработать реальный и логичный коммуникационный рассказ. Чтобы талисман был эффективным, ему необходимо простое и актуальное сообщение о сохранении. Талисманы привлекают больше всего, когда вызывают сочувствие, придавая своим персонажам физические и поведенческие черты, похожие на человеческие; сочувствие необходимо для развития заботы о животных и других видах. Помимо того, что талисман считается представителем команды и приносит удачу, он должен помогать больше узнавать о видах и их природной среде обитания, а также выступать за их выживание и защиту среды обитания. Вот некоторые примеры:

- $\quad$ Все 18 спортивных команд Атлантического университета Флориды известны как Совы, птица, традиционно ассоциируемая с мудростью и решимостью, служит талисманом университета. С 1971 года кампус школы в Бока-Ратон, Флорида, был местом особого заповедника кроличьей совы. Эта конкретная птица внесена в список «вызывающих озабоченность видов» во Флориде.

- К Карак был талисманом Игр Содружества 2006 года. Он был создан по образцу траурного какаду Бэнкса, находящегося под угрозой исчезновения в принимающей стране, Австралии.

- Броненосец Фулеко был официальным талисманом чемпионата мира по футболу 2014 года в Бразилии. Фулеко - это бразильский трёхполосный броненосец, вид броненосцев, который проживает в Бразилии и 
занесён в категорию уязвимых видов в Красную книгу угрожаемых видов МСОПТМ. Название представляет собой комбинацию слов Futebol (футбол) и Ecologia (экология).

От информационных панелей и специальных указателей до приложений для смартфонов, которые делятся видео и фотографиями биоразнообразия на суше или на воде, коммуникационные усилия могут способствовать долгосрочному пониманию зрителями ценности биоразнообразия и того, как можно помочь его улучшить. Кроме того, ту же информацию о биоразнообразии можно использовать для создания учебных программ для местных школ, чтобы научить учащихся важности сохранения биоразнообразия в их местной среде, или её можно использовать для создания музейных экспонатов о биоразнообразии на спортивном объекте.

Спортивные комментаторы также могут сыграть решающую роль. Они могут обогатить свои комментарии о мероприятии подробностями о местном биоразнообразии и мерах, принимаемых организаторами мероприятия. Кроме того, волонтёры, спортивные осициальные лица и персонал мероприятия также должны быть проинструктированы, чтобы они могли объяснить зрителям любые ограничения на просмотр, закрытые зоны и т.д., а также их причины. Будут ли соблюдаться меры по защите биоразнообразия или нет может иметь решающее значение.

Повышая осведомлённость общественности о важности сохранения биоразнообразия, спортсмены могут быть очень эффективными послами биоразнообразия благодаря прямой связи со своими болельщиками. Звёзды спорта могут положительно влиять на отношение и поведение там, где у них есть местная связь. Например, бывший игрок баскетбола Яо Мин, родом из Шанхая, использует своё положение как образец для подражания, чтобы обратить вспять вековые китайские традиции, приведшие к сокращению популяций носорогов и слонов. Всемирно известная звезда футбола Криштиану Роналду является послом организации Mangrove Care в Индонезии на форуме, целью которого является повышение осведомлённости о важности сохранения биоразнообразия и мангровых экосистем на Бали.

\section{5 Расширение имеющихся данных и знаний о биоразнообразии}

Когда для проведения спортивных мероприятий выбираются природные территории, редко бывает известно заранее, какие виды животных и растений существуют в этом районе и вокруг него, и, в частности, где они расположены. Кадастры биоразнообразия и исходные данные, часто требуются в рамках процесса планирования объекта и процесса получения разрешения на застройку, поэтому являются источниками новых знаний о территории для организаций по сохранению биоразнообразия, часто не имеющих средств для сбора такого объёма данных (например, университеты, исследовательские центры, неправительственные организации). Строители объектов и местные организационные комитеты имеют прекрасную возможность поддержать сохранение природы в будущем, сделав эти данные общедоступными.

\section{6 Получение выгод для биоразнообразия за счёт компенсации выбросов углерода}

\begin{abstract}
Как и при любой человеческой деятельности, спортивные соревнования, даже самые хорошо спланированные и хорошо организованные, должны стремиться компенсировать выбросы парниковых газов, возникающие в результате деятельности, на этапах планирования и проведения. При выборе проекта компенсации выбросов углерода спортивные организаторы могут отдавать приоритет проектам, которые также будут приносить сопутствующие выгоды для биоразнообразия.
\end{abstract}

Как правило, проекты по управлению земельными ресурсами нацелены на получение чистой положительной пользы для смягчения последствий изменения климата для мест- ных сообществ и для биоразнообразия. Например, проекты компенсации выбросов углерода на основе лесов предлагают хорошие возможности для достижения углеродной нейтральности за счёт решения проблемы деградации земель, одной из основных причин глобального изменения климата, а также обеспечивают ряд сопутствующих выгод, таких как поддержка местных сообществ путём обеспечения непрерывного предоставления важных экосистемных услуг, предоставляемых малонарушенными лесами. Углеродные проекты в лесах также обеспечивают прямую занятость членов сообщества, приносят доход и поддерживают инициативы в области социального и экономического развития. 


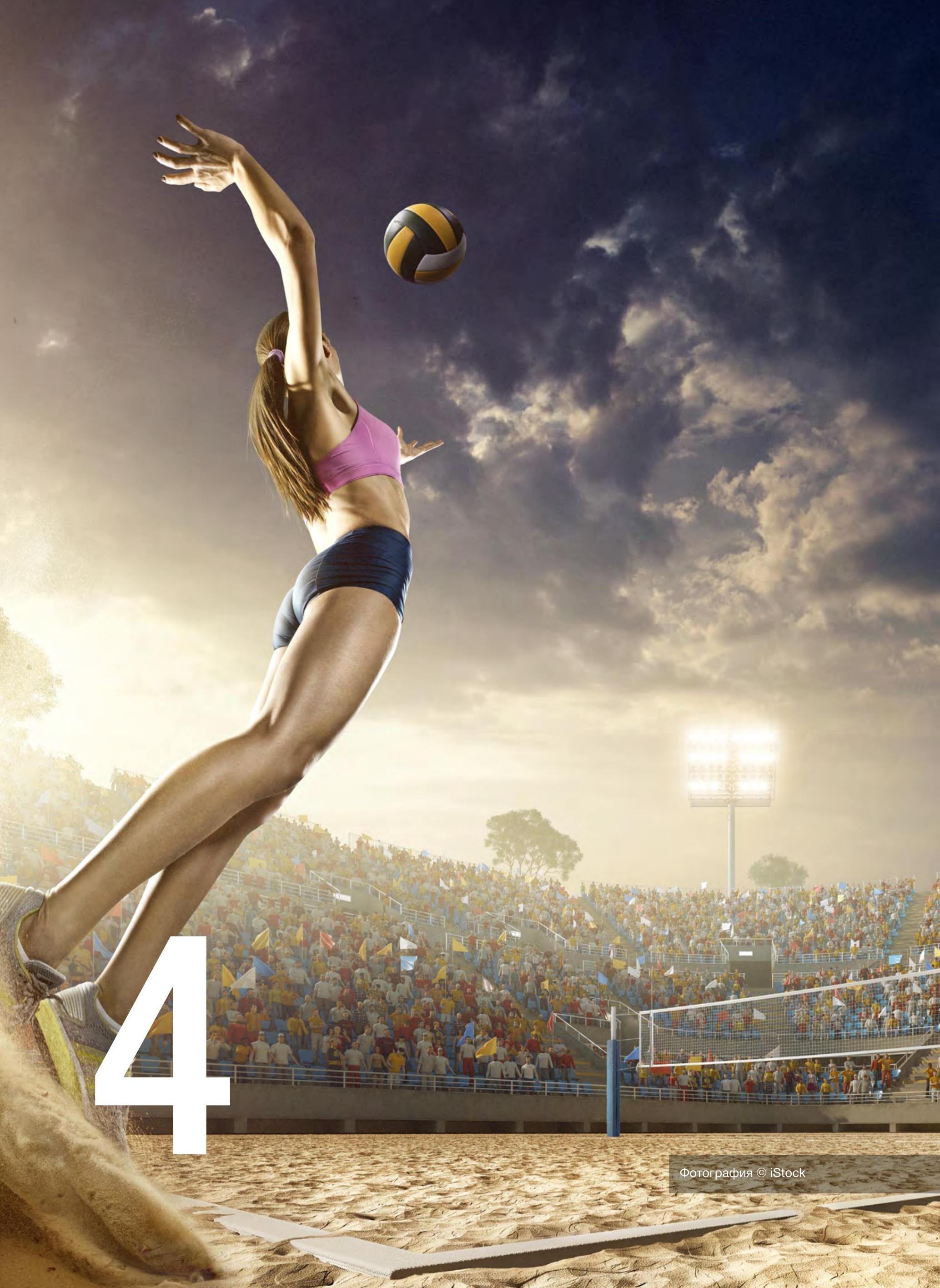




\section{4. Контрольный список действий для снижения риска и использования возможностей}

В следующей таблице представлен ряд областей действий и связанных с ними наводящих вопросов, которые помогут разработчикам, организаторам и спонсорам спортивных объектов и спортивных мероприятий выявлять и устранять потенциальные негативные воздействия на биоразнообразие в результате их деятельности, а также возможности для улучшения сохранения биоразнообразия.

\begin{tabular}{|c|c|}
\hline Область действий & Предлагаемые вопросы \\
\hline $\begin{array}{l}\text { 1. Определите, могут ли } \\
\text { место (-а) и мероприятие } \\
\text { (-я) повлиять на } \\
\text { биоразнообразие }\end{array}$ & $\begin{array}{l}\text { • } \quad \text { Будет ли мероприятие использовать существующие площадки или будут } \\
\text { построены новые? } \\
\text { • } \quad \text { пыл ли назначен эколог (или специалист по биоразнообразию) в группу } \\
\text { • } \quad \text { чтанирования и проектирования? } \\
\text { подробная карта распределения местных ценностей биоразнообразия, } \\
\text { таких как охраняемые районы, ключевые районы биоразнообразия } \\
\text { или находящиеся под угрозой исчезновения места обитания видов или } \\
\text { экосистем? } \\
\text { Места проведения соревнований расположены или строятся на территории } \\
\text { объектов всемирного наследия или охраняемых территорий? } \\
\text { Есть ли в зоне воздействия какие-либо «критические среды обитания» (см. } \\
\text { Вставку 2)? } \\
\text { Была ли проведена оценка издержек этих воздействий на сообщество? } \\
\text { • } \quad \text { Была ли проведена оценка затрат на смягчение воздействия на } \\
\text { биоразнообразие? } \\
\text { Была ли проведена оценка преимуществ смягчения воздействия на важные } \\
\text { экосистемные услуги, предоставляемые затронутым биоразнообразием? }\end{array}$ \\
\hline $\begin{array}{l}\text { Свяжитесь с } \\
\text { заинтересованными } \\
\text { сторонами }\end{array}$ & $\begin{array}{l}\text { • } \\
\text { • } \\
\text { Свществуют ли известные природоохранные проблемы в этом районе? } \\
\text { соответствующих случаях, с международными? } \\
\text { • } \quad \text { Были ли установлены контакты с соответствующими исследовательскими } \\
\text { учреждениями? }\end{array}$ \\
\hline $\begin{array}{l}\text { Поймите влияние места } \\
\text { проведения соревнований } \\
\text { и спортивного } \\
\text { мероприятия на } \\
\text { биоразнообразие }\end{array}$ & $\begin{array}{l}\text { • } \\
\text { Было ли проведено подробное базовое исследование биоразнообразия в } \\
\text { • } \\
\text { Байоне для определения важного биоразнообразия? } \\
\text { которые могут усугубиться местом проведения соревнований или } \\
\text { спортивным мероприятием? } \\
\text { • } \quad \text { была ли запланирована или проведена оценка воздействия на окружающую } \\
\text { среду для новых спортивных сооружений и мероприятий, чтобы определить } \\
\text { потенциально значительные негативные воздействия и способы их } \\
\text { смягчения? }\end{array}$ \\
\hline
\end{tabular}




\begin{tabular}{|c|c|c|}
\hline & $\begin{array}{l}\text { Смягчите воздействия на } \\
\text { биоразнообразие }\end{array}$ & $\begin{array}{ll}\text { - } & \text { Были ли проанализированы воздействия, связанные с местом проведения } \\
\text { соревнований и спортивным мероприятием, с точки зрения возможности их } \\
\text { предотвращения и минимизации? } \\
\text { • При выборе новых площадок был ли отдан приоритет в пользу } \\
\text { деградированных участков? } \\
\text { Если критические места обитания, в частности, или природные места } \\
\text { обитания могут быть подвергнуты негативному воздействию, были ли } \\
\text { изучены все возможные альтернативные участки для места проведения или } \\
\text { мероприятия, которые позволили бы избежать этих воздействий? } \\
\text { - Были ли рассмотрены и включены в планы реализации способы избежать } \\
\text { и минимизировать воздействия, связанные с местом проведения и } \\
\text { мероприятиями? } \\
\text { Было ли восстановление затронутой среды обитания оценено на предмет его } \\
\text { осуществимости и включено в планы реализации? } \\
\text { Были ли исчерпаны, определены и включены в планы реализации } \\
\text { компенсации биоразнообразия для воздействий, остающихся после усилий } \\
\text { по предотвращению, минимизации и восстановлению? } \\
\text { Удовлетворена ли необходимость совместных природоохранных действий } \\
\text { путём установления партнёрских отношений с природоохранными } \\
\text { организациями и научно-исследовательскими учреждениями? }\end{array}$ \\
\hline & $\begin{array}{l}\text { Используйте возможности } \\
\text { биоразнообразия }\end{array}$ & $\begin{array}{ll}\text { • } & \text { Были ли использованы возможности для улучшения или восстановления } \\
\text { местных деградированных местообитаний или воссоединения } \\
\text { фрагментированных местообитаний? } \\
\text { • } \quad \text { Были ли рассмотрены возможности увеличения или расширения охраняемых } \\
\text { территорий? } \\
\text { • Предоставлялись ли данные, собранные в ходе оценки биоразнообразия, } \\
\text { соответствующим природоохранным и исследовательским учреждениям? } \\
\text { Были ли включены нацеленные на общественность программы просвещения } \\
\text { и информирования о биоразнообразии в проведение спортивных } \\
\text { мероприятий? } \\
\text { Были ли определены и запланированы варианты сбора средств для } \\
\text { управления охраняемыми территориями и местных природооранных } \\
\text { инициатив? }\end{array}$ \\
\hline
\end{tabular}




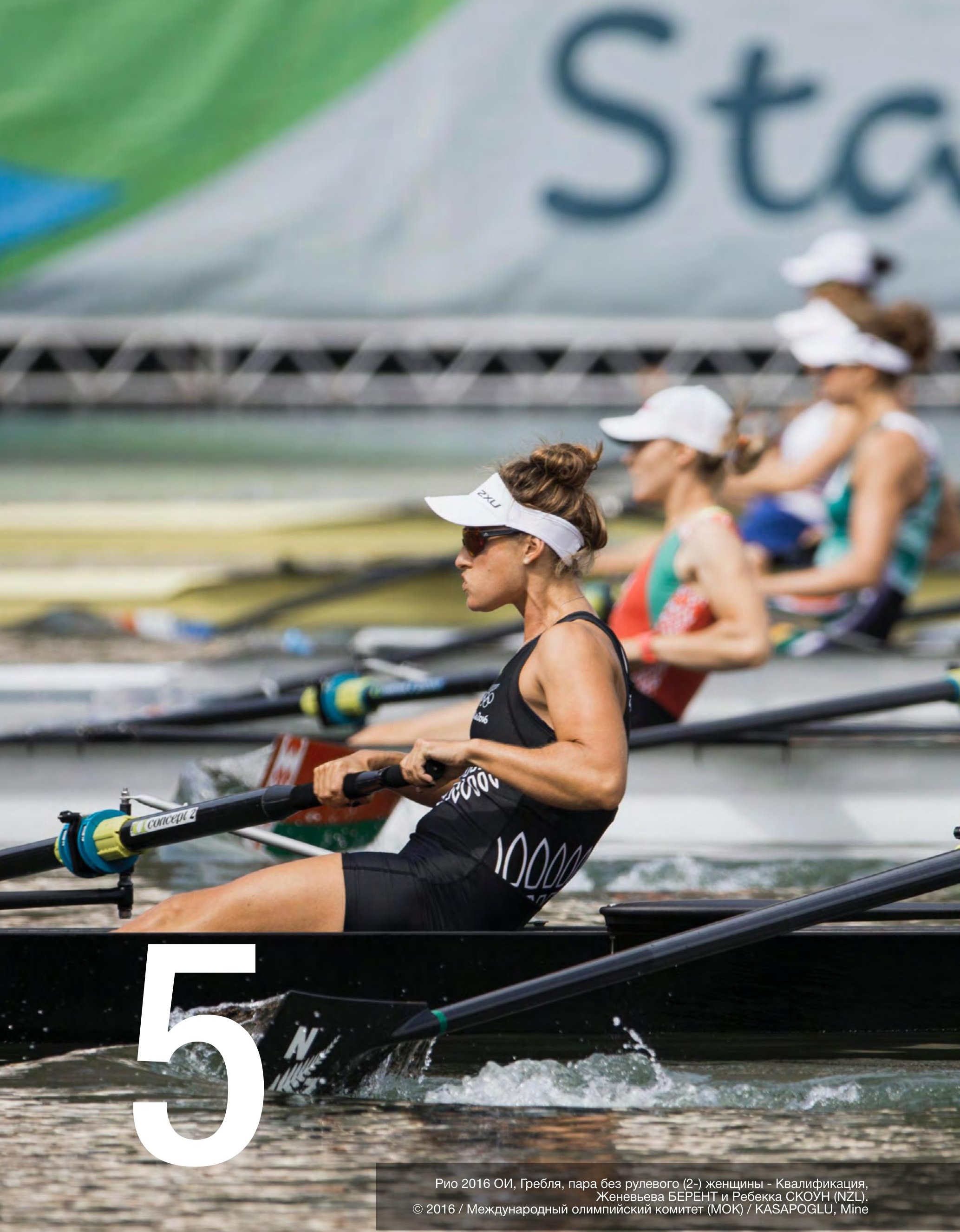




\section{5. Словарь терминов и источники информации}

\section{1. Словарь терминов}

\begin{abstract}
Биологическое разнообразие: вариабельность живых организмов из всех источников, включая, среди прочего, наземные, морские и иные водные экосистемы и экологические комплексы, частью которых они являются; это понятие включает в себя разнообразие в рамках вида, между видами и разнообразие экосистем. (Конвенция о биологическом разнообразии, 1992г.)
\end{abstract}

Утрата биоразнообразия: Утрата биоразнообразия обычно наблюдается как одно или всё из: (1) сокращение площади, занимаемой популяциями, видами и типами сообществ, (2) утрата популяций и генетического разнообразия, которое они вносят в весь вид, и (3) снижение численности (популяций и видов) или состояния (сообществ и экосистем). Вероятность сохранения какого-либо компонента биоразнообразия (вероятность сохранения) в долгосрочной перспективе снижается с уменьшением численности и генетического разнообразия, а также с уменьшением площади местообитаний. (Словарь (2012г.), ВВОР)

Компенсация биоразнообразия: Компенсация биоразнообразия - это измеримые результаты сохранения биоразнообразия в результате действий, направленных на компенсацию значительных остаточных неблагоприятных воздействий на биоразнообразие, возникающих в результате реализации проекта после принятия соответствующих мер по смягчению последствий. Цель компенсации биоразнообразия - добиться отсутствия чистых потерь, а лучше - чистого прироста биоразнообразия на земле в отношении состава видов, структуры среды обитания и экосистемных функций, использования людьми и культурных ценностей, связанных с биоразнообразием. (Словарь (2012г.), ВВОР)

Кумулятивное воздействие: Суммарное воздействие от проекта (под контролем застройщика); других видов деятельности (которые могут находиться под контролем других, в том числе других застройщиков, местных сообществ, правительства); и других фоновых фракторов давления и тенденций, которые могут быть нерегулируемыми. Таким образом, воздействие проекта является частью общего совокупного воздействия на окружающую среду. Анализ дополнительных воздействий проекта в сочетании с эффектами других проектов часто может дать более точное понимание вероятных результатов присутствия проекта, чем просто рассмотрение его воздействий в изоляции.
(Словарь (2012г.), ВВОР)

Прямое воздействие: результат, напрямую связанный с определённым действием или деятельностью по проекту (часто также называемый первичным воздействием). (СлоBapb (2012г.), BBOP)

Экосистема: динамичный комплекс сообществ растений, животных и микроорганизмов, а также их неживой окружающей среды, взаимодействующих как единое функциональное целое. (Конвенция о биологическом разнообразии, 1992г.)

Экосистемный подход: стратегия комплексного управления земельными, водными и живыми ресурсами, которая способствует сохранению и устойчивому использованию на справедливой основе. (Конвенция о биологическом разнообразии, 2010г.)

Экосистемные услуги: выгоды, которые люди получают от экосистем. К ним относятся такие услуги, как еда, вода, древесина и волокна; регулирующие услуги, влияющие на климат, наводнения, болезни, отходы и качество воды; культурные услуги, обеспечивающие рекреационные, эстетические и духовные блага; и вспомогательные услуги, такие как почвообразование, фотосинтез и круговорот питательных веществ. (Словарь (2012г.), ВВОР)

Место обитания: означает тип местности или место естественного обитания того или иного организма или популяции. (Конвенция о биологическом разнообразии, 1992г.)

Косвенные воздействия: воздействия, возникшие в результате присутствия проекта, а не непосредственно вызванные собственно реализацией проекта; иногда их называют вторичными или индуцированными воздействиями. (Словарь (2012г.), ВВОР)

Инвазивные чужеродные виды: Инвазивные чужеродные виды (ИЧВ) - это виды, которые укоренились вне своего природного прошлого или настоящего ареала, интродукция или распространение которых угрожают биологическому разнообразию. (Конвенция о биологическом разнообразии, 1992г.) 
Ключевые районы биоразнообразия: КРБ - это участКИ, вносящие значительный вклад в глобальную устойчивость биоразнообразия.Глобальный стандарт определения ключевых районов биоразнообразия, версия 1.0, МсоП 2016г.)

Иерархия смягчения: иерархия смягчения определяется каK:

1. Предотвращение: принятые с самого начала меры для предотвращения воздействия, такие как тщательное пространственное или временное размещение элементов инфраструктуры, чтобы полностью избежать воздействия на определённые компоненты биоразнообразия.

2. Минимизация: меры, принятые для уменьшения продолжительности, интенсивности или степени воздействия, включая, при необходимости, прямые, косвенные и кумулятивные воздействия (в том числе от изменения климата), которых невозможно полностью избежать, насколько это практически возможно достичь.

3. Реабилитация/восстановление: меры, принятые для реабилитации деградированных экосистем или восстановления очищенных после воздействий экосистем, которые нельзя полностью избежать или минимизировать.

4. Компенсация: меры, принятые для компенсации любых остаточных значительных неблагоприятных воздействий, которых нельзя избежать, минимизировать, реабилитировать или восстановить, чтобы достичь отсутствия чистых потерь биоразнообразия или чистого прироста биоразнообразия. Компенсация может принимать форму позитивных управленческих вмешательств, таких как восстановление деградированной среды обитания; остановленная деградация; или предотвращение риска путём защиты территорий, где наблюдается неминуемая или прогнозируемая потеря биоразнообразия. (Словарь (2012г.), ВВОР)

Нет чистых убытков/чистая прибыль/чистые положительные воздействия: цель для проекта застройки, в котором воздействия на биоразнообразие, вызванные проектом, уравновешиваются или перевешиваются мерами, принимаемыми для предотвращения и минимизации воздействий проекта, чтобы предпринять восстановление участка и, наконец, компенсация остаточных воздействий, чтобы не осталось потерь. Если прибыль превышает убыток, вместо чистых убытков можно использовать термины «чистая прибыль» или «чистое положительное влияние». Отсутствие чистой потери (или чистой выгоды) биоразнообразия является политической целью в нескольких странах, а также целью добровольной компенсации биоразнообразияs. (Словарь (2012г.), ВВОР)

Принцип предосторожности: в тех случаях, когда существует угроза серьёзного или необратимого ущерба, отсутствие полной научной уверенности не используется в качестве причины для отсрочки принятия экономически эффективных мер по предупреждению ухудшения состояния окружающей среды. (Рио-де-Жанейрская декларация, 1992г., Принцип 15)

Охраняемая территория: чётко определённое географическое пространство, признанное, выделенное и управляемое с помощью юридических или других эффективных средств для достижения долгосрочного сохранения природы с соответствующими экосистемными услугами и культурными ценностями. (Определение МСОП 2008г.)

Восстановление: процесс оказания помощи в восстановлении района или экосистемы, которые были деградированы, повреждены или разрушены. Целью экологического восстановления является восстановление состава, структуры и функции экосистемы, обычно возвращая её в исходное (до нарушения) состояние или в здоровое состояние, близкое к исходному. Экосистема восстанавливается, когда она содержит достаточно биотических и абиотических ресурсов для поддержания себя структурно и функционально и может продолжать своё развитие без дальнейшей помощи или субсидий. Она продемонстрирует устойчивость к нормальным диапазонам экологического стресса и нарушений и будет взаимодействовать с прилегающими экосистемами с точки зрения биотических и абиотических потоков и культурных взаимодействий. Экологическое восстановление направлено на изменение биоты и физических условий на участке, и его часто путают с реабилитацией. В то время как восстановление направлено на возвращение экосистемы в прежнее естественное состояние, реабилитация подразумевает использование ландшафта для нового или изменённого использования для определённых целей человека. Такие виды деятельности, как экологическая инженерия и различные виды управления ресурсами, включая управление дикой природой, рыболовством и пастбищами, агролесоводство и лесное хозяйство, могут квалифицироваться как экологическое восстановление, если они удовлетворяют критериям, установленным Обществом экологического восстановления, в котором перечислены девять атрибутов в качестве основы для определения завершения восстановления. (Общество экологического восстановления)

Подход, основанный на правах: это подход к сохранению, который уважает и стремится защищать и продвигать признанные стандарты прав человека. (МСОП).

Виды, находящиеся под угрозой исчезновения: это виды, 
отнесённые к категориям «находящиеся в критическом состоянии», «находящиеся под угрозой исчезновения» или «уязвимые» согласно Красной книге находящихся под угрозой исчезновения видов Мсоптм. Красная книга широко признана в качестве наиболее полного и объективного глобального подхода к оценке статуса сохранности видов растений и животных. (Красная книга находящихся под угрозой исчезновения видов МсОПтм)

\section{2 Источники информации}

A Cross-Sector Guide for Implementing the Mitigation Hierarchy («Межотраслевое руководство по реализации иерархии смягчения последствий») (2015), Cross Sector Biodiversity Initiative. http://www.csbi.org.uk/wp-content/ uploads/2015/09/CSBI-Mitigation-Hierarchy-Guide-Sept-2015-1.pdf

BBOP Standard on Biodiversity Offsets and associated material (Стандарт компенсации биоразнообразия ВВОР и сопутствующие материалы). http://bbop.forest-trends.org/pages/guidelines

Biodiversity for Business: A guide to using knowledge products delivered through IUCN («Биоразнообразие для бизнеса: руководство по использованию продуктов знаний, предоставляемых через МСОП») (2014), IUCN. https://portals.iucn.org/library/sites/library/files/documents/2014-004.pdf

Costanza, R, R de Groot, P Sutton, S van der Ploeg, S J. Anderson, I Kubiszewski, S Farber, R.K.Turner Changes in the global values of ecosystem services ( «Изменения в глобальной стоимости экосистемных услуг»), Global Environmental Change 26 (2014), стр.152-158. https://doi.org/10.1016/j.gloenvcha.2014.04.002

Cultural and Spiritual Value of Biodiversity («Культурная и духовная ценность биоразнообразия») (1999), United Nations Environment Programme, http://staging.unep.org/pdf/Cultural Spiritual thebible.pdf

Hardner, J, RE Gullison, S Anstee, and M Meyer. (2015). Good Practices for Biodiversity Inclusive Impact Assessment and Management Planning («Надлежащие практики комплексной оценки воздействия на биоразнообразие и планирования управления»). Prepared for the Multilateral Financing Institutions Biodiversity Working Group. https://publications.ladb.org/bitstream/handle/11319/7094/Good Practices for Biodiversity Inclusive Impact Assessment.pdf? sequence=1

Human Rights Indicators - A Guide to Measurement and Implementation («Показатели прав человека руководство по измерению и осуществлению») (2012), Office of the United Nations High Commissioner for Human Rights. United Nations. http://www.ohchr.org/Documents/Publications/Human_rights_indicators_en.pdf

IUCN Policy on Biodiversity Offsets (Политика МСОП в отношении компенсации биоразнообразия) (2016), IUCN . https://portals.iucn.org/library/sites/library/files/resrecfiles/WCC 2016 RES 059 EN.pdf

IFC Performance Standards on Environmental and Social Sustainability (Стандарты деятельности МФК в области экологической и социальной устойчивости) (2012). International Finance Corporation. https://www.ifc.org/wps/ wcm/connect/c8f524004a73daeca09afdf998895a12/IFC Performance Standards.pdf?MOD=AJPERES

Cambridge Conservation Initiative (2015). Strengthening implementation of the mitigation hierarchy: managing biodiversity risk for conservation gains. («Усиление реализации иерархии смягчения последствий: управление рисками для биоразнообразия в интересах сохранения»). - Collaborative Fund Project Report compiled by: BirdLife International, UNEP-WCMC, RSPB, FFI and the University of Cambridge. http://www.birdlife.org/sites/ default/files/attachments/cci report - managing risk for conservation gains - final - june 9th 2015.pdf

Conservation International. The value of carbon forest offset («Стоимость углеродной компенсации лесов») (2011). http://www.conservation.org/publications/Documents/2011 0414 Value of Forest Carbon Offsets.pdf 


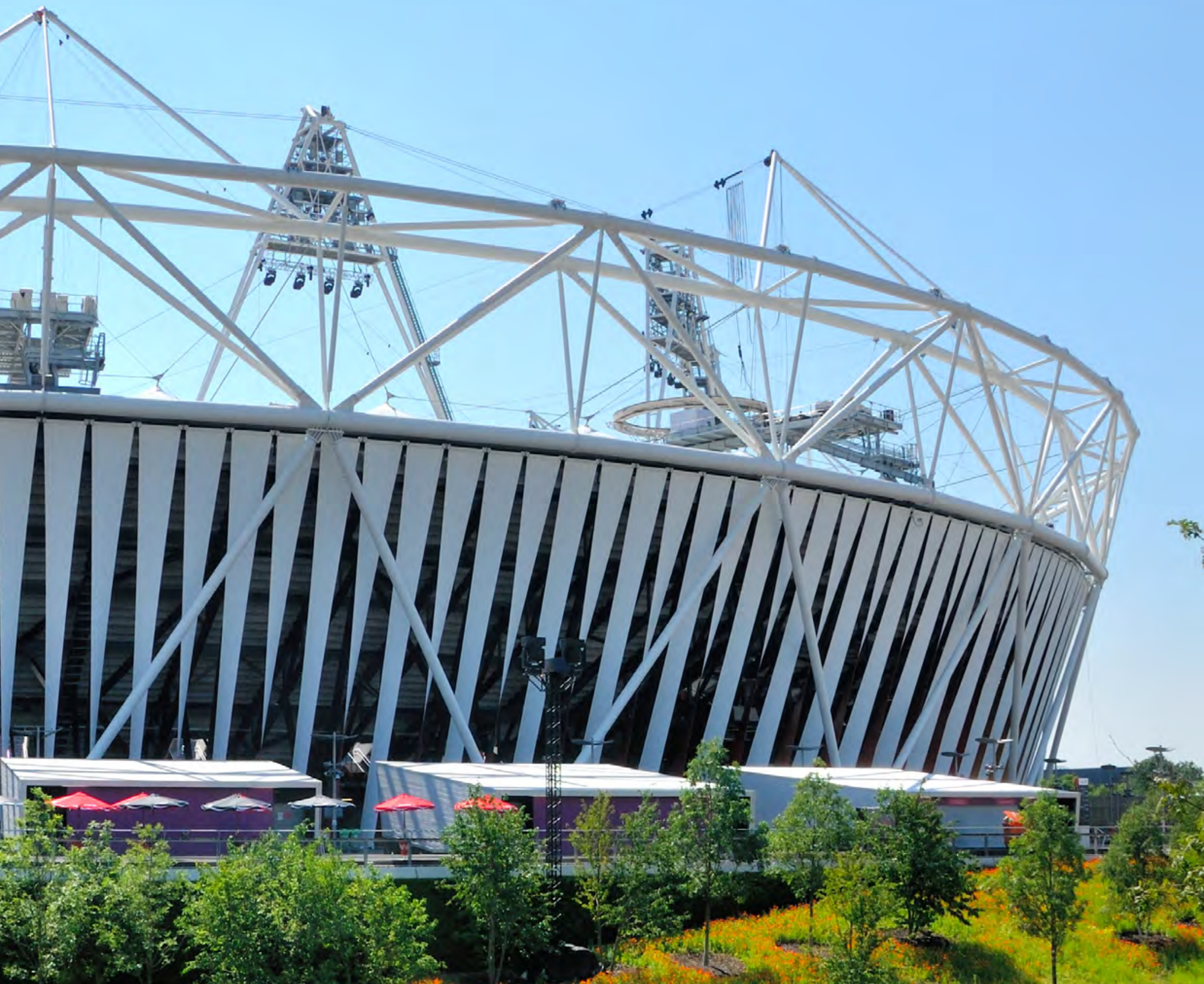
(5)

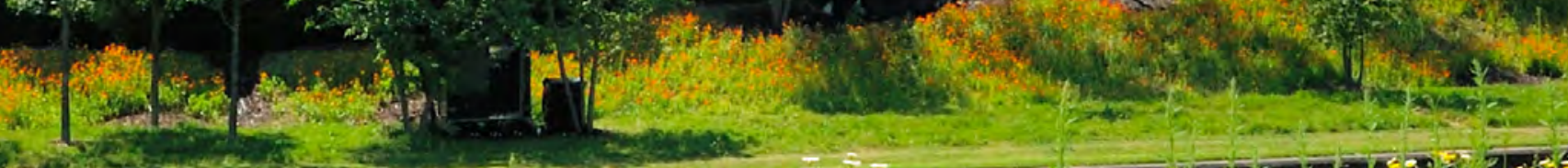

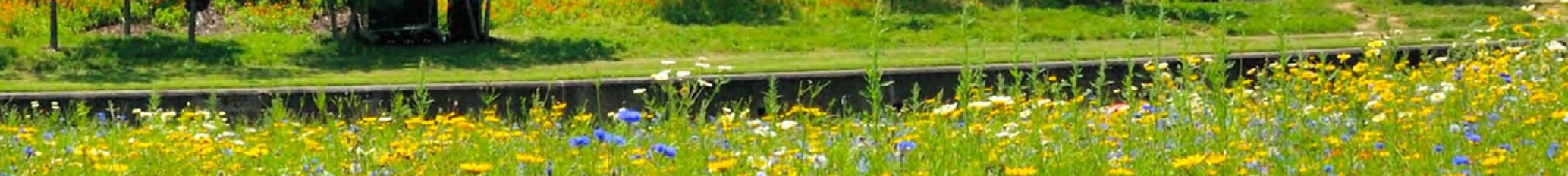

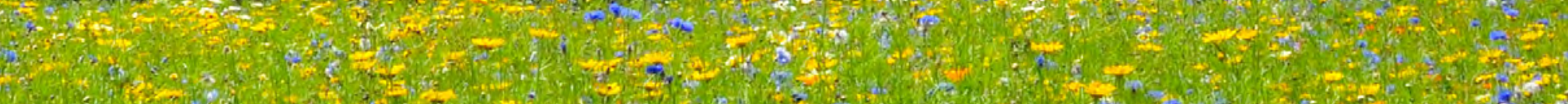

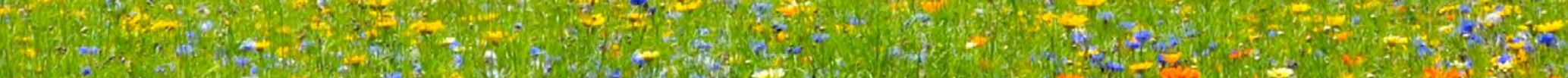

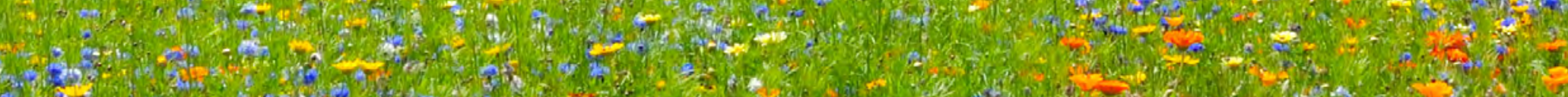
4.) 30 , sonm a 36. 2. (2) $\begin{aligned} \text { 17. } & \text {. }\end{aligned}$

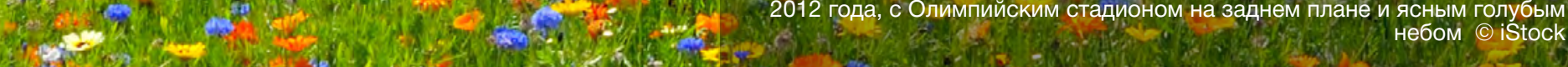
20.6.

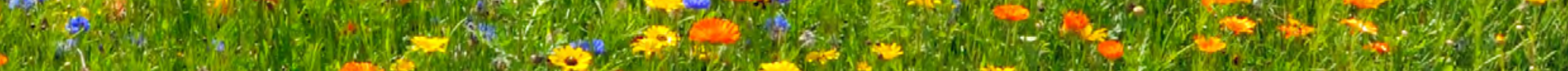

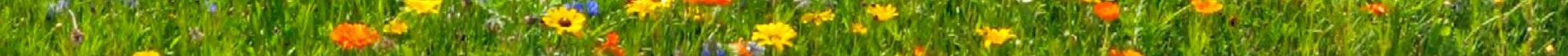






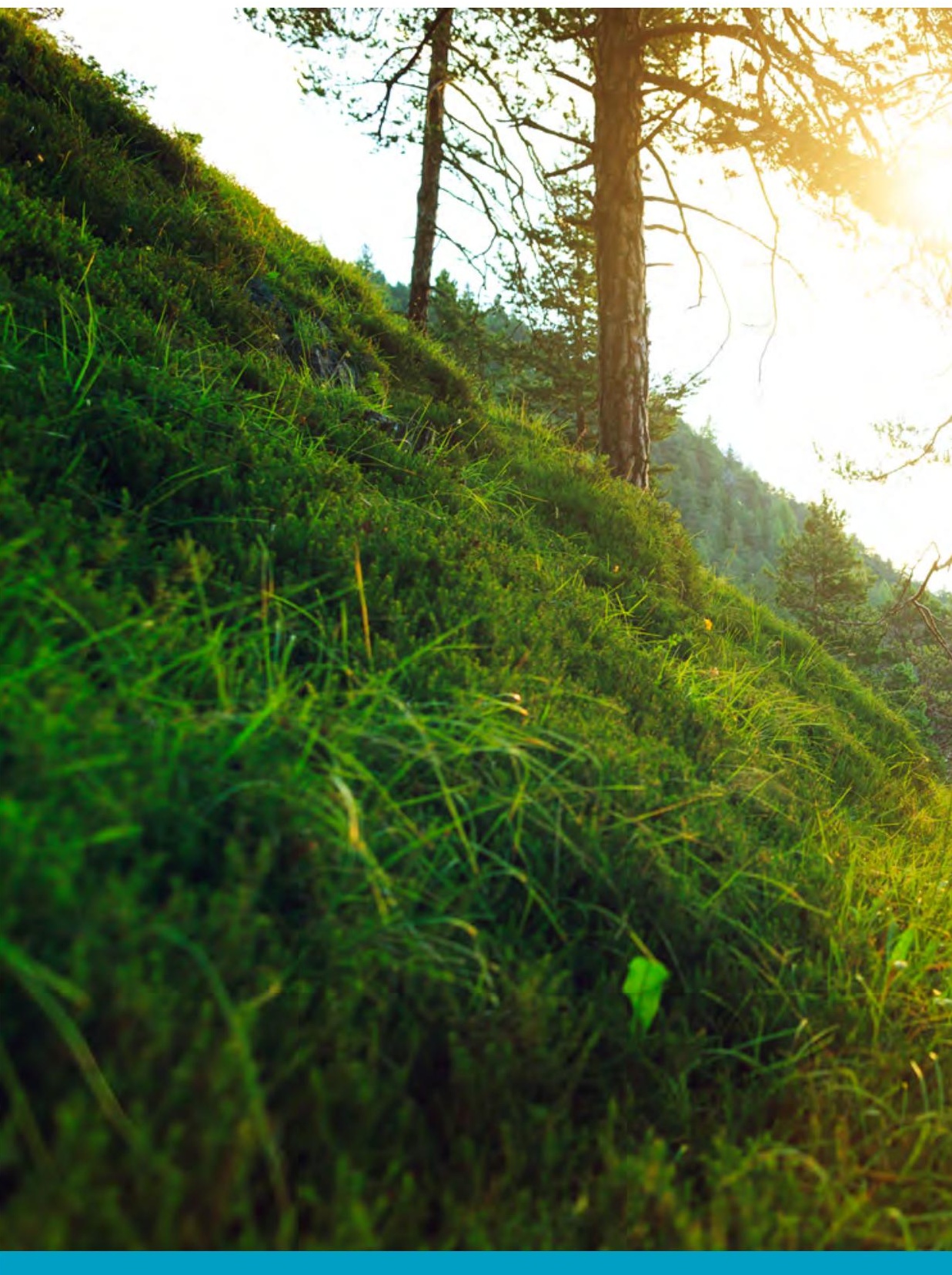

МЕЖДУНАРОДНЫЙ СОЮЗ ОХРАНЫ ПРИРОДЫ

ГЛОБАЛЬНАЯ ПРОГРАММА БИЗНЕС И БИОРАЗНООБРАЗИЕ

Rue Mauverney 28

1196 Gland

Tel +41229990000

Fax +41229990002

www.iucn.org 